\title{
Thermo-mechanical behaviour of energy piles
}

\author{
B. L. AMATYA*, K. SOGA†, P. J. BOURNE-WEBB $\$$, T. AMIS $\S$ and L. LALOUIף
}

\begin{abstract}
Energy piles are an effective and economic means of using geothermal energy resources for heating and cooling buildings, contributing to legislative requirements for renewable energy in new construction. While such piles have been used for around 25 years with no apparent detrimental effect, there is limited understanding of their thermo-mechanical behaviour. This paper synthesises the results from three published field studies and illustrates some of the engineering behaviour of such piles during heating and cooling. Simplified load transfer mechanisms for a single pile subjected to pure thermal loadings (i.e. without mechanical load) and combined thermomechanical loadings have been developed and are used to interpret the field data with regard to change in axial stress and shaft friction during heating and cooling. The effect of end restraint and ground conditions on the thermo-mechanical response of energy piles is discussed. Values of change in axial stress and mobilised shaft friction due to thermal effects that may be useful in the design of energy piles are presented.
\end{abstract}

KEYWORDS: design; field instrumentation; full-scale tests; piles; stress analysis; temperature effects
Les pieux énergétiques sont un moyen à la fois efficace et utile d'exploiter des ressources d'énergie géothermiques pour le chauffage et le refroidissement de bâtiments, tout en se conformant aux stipulations de la législation pour l'énergie renouvelable dans des constructions nouvelles. Bien que ces pieux soient utilisés depuis environ 25 ans sans aucun effet délétère apparent, les connaissances sur leur comportement thermo-mécanique restent limitées. La présente communication résume les résultats publiés de trois études sur le terrain, et illustre certains comportements techniques de ces pieux au cours du chauffage et le refroidissement. Des mécanismes simplifiés de transfert de la charge pour un pieu unique soumis à des charges thermiques pures (autrement dit sans charge mécanique) et des charges thermo-mécaniques mixtes ont été développés, et sont utilisés pour interpréter les données sur le terrain relativement aux changements dans les contraintes axiales et le frottement latéral au cours du chauffage et du refroidissement. On se penche sur l'effet de l'encastrement et de l'état du sol sur la réaction thermomécanique des pieux énergétiques, et on présente des valeurs de variations des contraintes axiales et de la friction latéral mobilisée en conséquence d'effets thermiques, qui pourront être utiles pour la conception des pieux énergétiques.

\section{INTRODUCTION}

In recent years, ground source heat pump (GSHP) systems have emerged as a promising technology for heating and cooling buildings. GSHP systems circulate a fluid between the heat pump and heat exchange elements in the ground; cooler fluid is circulated to extract energy from the warmer ground for heating, and the fluid transfers building heat to the ground to provide cooling. It is possible to incorporate the mechanism for heat transfer between the building and the ground in the foundation elements. The use of building piles as heat exchangers within the ground has broad appeal, because concrete is an ideal medium as the heat absorber in the ground, owing to its good thermal conductivity and thermal storage capacity.

Notwithstanding their successful operational use in some countries such as Austria (Brandl, 2006) and Germany (Ennigkeit \& Katzenbach, 2001), the uptake of energy foundations in other countries has been limited. In the UK, this is partly due to concerns in parts of the construction industry regarding the potential impact of temperature cycles on the performance of the foundation elements (load capacity and settlement issues). During heating and cooling

Manuscript received 27 October 2010; revised manuscript accepted 3 August 2011.

Discussion on this paper closes on 1 November 2012; for further details see p. ii.

* Halcrow Group Limited, London, UK (formerly University of Cambridge).

$\dagger$ University of Cambridge, UK.

\$ Geotechnical Engineer, Lisbon, Portugal (formerly Cementation Skanska Limited).

§ Geothermal International Ltd, Coventry, UK.

If Swiss Federal Institute of Technology Lausanne, EPFL, Switzerland. cycles, the concrete of the energy pile expands and contracts, and this alters the pile-soil interactions. While there are no known examples of foundation failure due to these thermal interactions, better understanding of the mechanisms of response will allow more refined design guidance and avoid excessive conservatism.

In this paper, results from the field trials performed in London, UK (Amis et al., 2008; Bourne-Webb et al., 2009) and in Lausanne, Switzerland (Laloui et al., 2006) are synthesised in order to develop pile-soil interaction mechanisms applicable to GSHP operation. Also, data from field instrumentation at Bad Schallerbach, Austria, reported by Brandl $(1998,2006)$ are discussed in relation to the mechanisms developed. By doing so, the paper also provides indicative values for these thermal effects that may prove useful during design of energy piles in similar circumstances.

\section{ENERGY PILE FIELD TRIALS}

Lambeth College, London, UK

The test site is located within the grounds of the Clapham Centre of Lambeth College in South London. Fig. 1(a) shows the ground profile and pile geometry. The undrained shear strength profile was evaluated solely from standard penetration test (SPT) data. Details of the test set-up, the instrumentation and the layout of the test elements are described in Table 1, Amis et al. (2008) and Bourne-Webb et al. (2009).

A mechanical load of $1200 \mathrm{kN}$ was applied to the main test pile. The boundary condition at the pile head is one of load control, and the pile head is free to move as the load cell adjusts to maintain the load. The heat sink pile was used purely for heat exchange, and no load or restraint was provided at its head. The main test pile, two of the anchor 


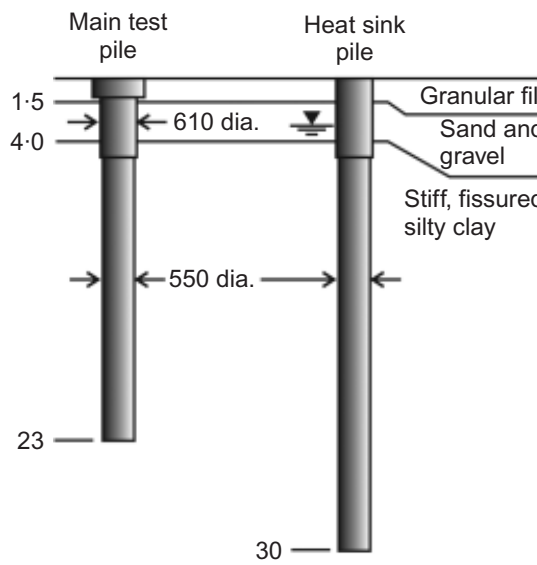

Typical soil properties

\begin{tabular}{|l|l|}
\hline $\begin{array}{l}\text { Granular fill and } \\
\text { sand and gravel }\end{array}$ & $\begin{array}{l}\gamma=19 \mathrm{kN} / \mathrm{m}^{3} \\
c^{\prime}=0, \phi^{\prime}=35^{\circ}\end{array}$ \\
\hline $\begin{array}{l}\text { Stiff, fissured } \\
\text { silty clay }\end{array}$ & $\begin{array}{l}\gamma=20 \mathrm{kN} / \mathrm{m}^{3} \\
c_{\mathrm{u}}=65+8 \cdot 2 z \mathrm{kPa}\end{array}$ \\
\hline
\end{tabular}

Note:

$z=$ depth below top of clay layer: $m$

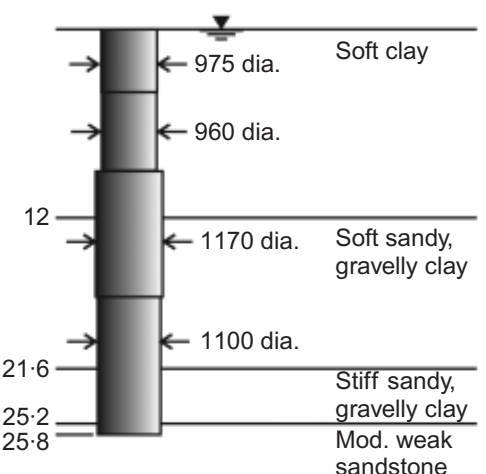

(a)

Typical soil properties
\begin{tabular}{|l|l|}
\hline Soft clay & $\begin{array}{l}\gamma=19 \cdot 6 \mathrm{kN} / \mathrm{m}^{3} \\
c_{\mathrm{u}}=15-20 \mathrm{kPa}\end{array}$ \\
\hline $\begin{array}{l}\text { Soft sandy, } \\
\text { gravelly clay }\end{array}$ & $\begin{array}{l}\gamma=19 \cdot 1 \mathrm{kN} / \mathrm{m}^{3} \\
c_{\mathrm{u}}=20-30 \mathrm{kPa}\end{array}$ \\
\hline $\begin{array}{l}\text { Stiff sandy, } \\
\text { gravelly clay }\end{array}$ & $\begin{array}{l}\gamma=21 \cdot 6 \mathrm{kN} / \mathrm{m}^{3} \\
c_{\mathrm{u}}=70-150 \mathrm{kPa}\end{array}$ \\
\hline $\begin{array}{l}\text { Mod. weak. } \\
\text { sandstone }\end{array}$ & $\begin{array}{l}\gamma=25 \mathrm{kN} / \mathrm{m}^{3} \\
\mathrm{UCS}=12 \mathrm{MPa}\end{array}$ \\
\hline
\end{tabular}

(b)

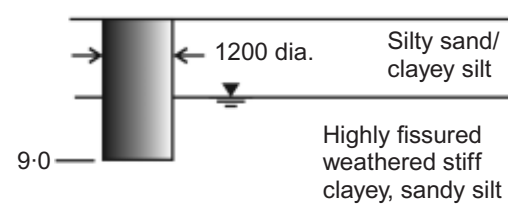

Typical soil properties

\begin{tabular}{|l|l|}
\hline $\begin{array}{l}\text { Silty sand/ } \\
\text { clayey silt }\end{array}$ & $\begin{array}{l}c^{\prime}=10-100 \mathrm{kPa} \\
\phi^{\prime}=25-35^{\circ}\end{array}$ \\
\hline $\begin{array}{l}\text { Stiff, fissured } \\
\text { clayey sandy silt }\end{array}$ & $\begin{array}{l}\gamma=17-21 \mathrm{kN} / \mathrm{m}^{3} \\
c_{\mathrm{u}}=15-300 \mathrm{kPa}\end{array}$ \\
\hline
\end{tabular}

(c)

Fig. 1. Ground profile and pile geometry at test locations: (a) London; (b) Lausanne; (c) Bad Schallerbach

Table 1. Summary details of three test sites

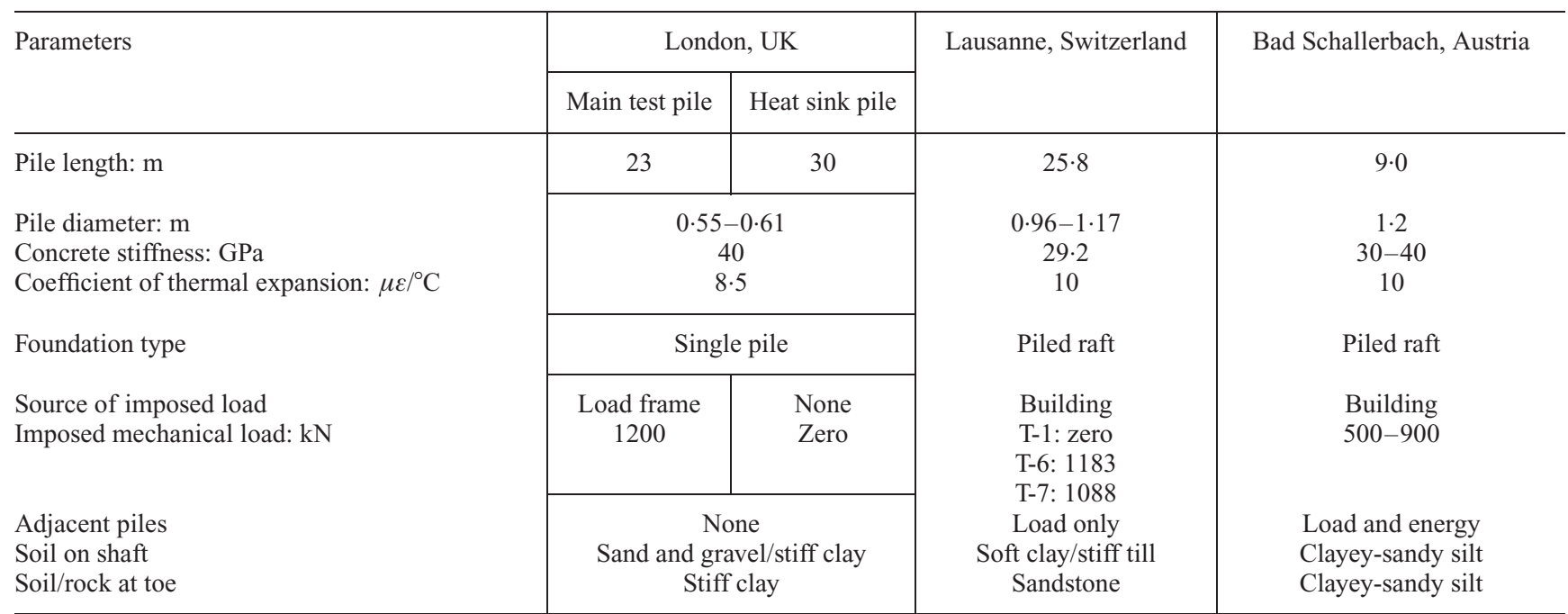


piles and the heat sink pile were fitted with optical fibre sensors (OFS) for measuring both strain and temperature.

Testing was conducted over 53 days. A vertical load of $1200 \mathrm{kN}$ was maintained on the main test pile for 46 of the 53 days. During this period the pile was cooled for 31 days, heated for 12 days, and then cooled and heated in daily cycles for three days. The thermal load applied to the heat sink pile was the reverse of that applied to the main test pile. The magnitude of the applied thermal load was significantly higher than that used in conventional GSHP operations.

\section{Lausanne, Switzerland}

This field trial was undertaken at École Polytechnique Fédérale de Lausanne (EPFL), Switzerland, during the construction of a new building on the campus. The soil profile, groundwater level and pile dimensions are shown in Fig. 1(b). Complete details of the test can be found in Table 1 and Laloui et al. (2003, 2006).

The pile is located at the edge of a four-storey building, which was under construction during the period of testing and served not only as a load-bearing element but also as an energy exchanger. The remaining piles supporting the building performed solely as load-bearing elements, that is, only the test pile was thermally loaded. Instrumentation installed in the pile included optical fibre sensors, extensometers and a load cell located at the pile base.

Thermal testing was carried out at intervals coinciding with the completion of each floor during construction of the building. Thus each thermal test consisting of a heating and recovery phase was undertaken with a different head load, each test lasting for about 28 days. The instrumented pile was subjected to seven heating and recovery cycles from T-1 (without any vertical building load) to T-7 (with the maximum imposed load due to building self-weight, about $1300 \mathrm{kN}$ ) (Laloui et al., 2006).

\section{Bad Schallerbach, Austria}

An instrumented pile, forming part of an operational GSHP system of 143 piles, was installed during construction works for a rehabilitation centre in Bad Schallerbach, Austria (Brandl, 1998, 2006). The pile dimensions and ground profile are shown in Fig. 1(c). The details of the project, the pile and its instrumentation, and the monitoring results are described in Table 1 and Brandl $(1998,2006)$.

The piles are part of a piled raft, supporting a seven-storey building that is benched into a sloping site. The test pile was equipped with pressure cells at the toe and the head, 'fissuremeters' at three levels, and 'thermo-elements' at five levels. Data were collected intermittently at different times of the year over several years operation of the GSHP system.

Brandl $(1998,2006)$ reports that the foundation work was completed in 1994-1995, and that the structure of the building with $90 \%$ of the dead load in place was completed in the autumn of 1996. The GSHP system became fully operational one year later. In this paper, the data obtained in the interval between February 1996 and February 1998 were used for comparison.

\section{PILE-SOIL INTERACTION UNDER THERMAL LOADING ONLY}

When a pile under working load is heated or cooled, a complex behaviour is imposed upon the pile that varies with different ground conditions and different degrees of end restraint. First, pile thermal response without any mechanical load applied will be considered using the data from the London heat sink pile and the Lausanne T-1 test, which were obtained in such conditions. Then, in a later section, the impact of thermo-mechanical loading will be examined based on the results from the London main test pile, Lausanne tests T-6 and T-7 and Bad Schallerbach.

The sign convention adopted is

(a) thermal expansive strain due to heating in the pile: positive

(b) tensile strain in the pile: positive

(c) tensile axial load or stress in the pile: positive

(d) shaft resistance acting upward: positive.

\section{Conceptual background}

When a pile without a head load is heated, it expands. If it is a free-standing column, it will expand as per its thermal characteristics according to the equation

$$
\varepsilon_{\mathrm{T}-\mathrm{Free}}=\alpha_{\mathrm{c}} \Delta T
$$

where $\varepsilon_{\mathrm{T} \text {-Free }}$ is the free axial thermal strain without any restraint, $\alpha_{\mathrm{c}}$ is the coefficient of thermal expansion/contraction of concrete and $\Delta T$ is the net change in temperature of the pile.

A pile placed in the ground will not be able to expand freely, owing to mobilisation of side restraint at the pile-soil interface and any end restraint either at the pile head or toe. Thus the measured strain change due to temperature change $\left(\varepsilon_{\mathrm{T}-\mathrm{Obs}}\right)$ will be less than that given by equation (1)

$$
\varepsilon_{\mathrm{T}-\mathrm{Obs}} \leqslant \varepsilon_{\mathrm{T} \text {-Free }}
$$

The restrained axial strain $\varepsilon_{\mathrm{T}-\mathrm{Rstr}}$ can be estimated as

$$
\varepsilon_{\mathrm{T}-\mathrm{Rstr}}=\varepsilon_{\mathrm{T} \text {-Free }}-\varepsilon_{\mathrm{T} \text {-Obs }}
$$

The restrained strain $\varepsilon_{\mathrm{T} \text {-Rstr }}$ creates thermal stress in the pile, and should be considered in structural design. For a given strain increment due to a temperature change, a thermally induced axial load can be estimated using the equation

$$
\begin{aligned}
P_{\mathrm{T}} & =-E A \varepsilon_{\mathrm{T}-\mathrm{Rstr}} \\
& =-E A\left(\alpha_{\mathrm{c}} \Delta T-\varepsilon_{\mathrm{T}-\mathrm{Obs}}\right)
\end{aligned}
$$

where $E$ is the Young's modulus of the pile material, and $A$ is the cross-sectional area of the pile. The negative sign in equation (4) implies that the restrained strain due to pilesoil interaction provides a counterforce to restrict the pile deformation.

In order to examine the effect of these changes, a pile with uniform cross-sectional area installed in an idealised rigid plastic soil with uniform shaft resistance and negligible base resistance is considered. When the temperature change is uniform over the entire length of the pile, as was observed in the London (Amis et al., 2008) and Lausanne (Laloui et al., 2003) cases, a simplified set of axial deformation, axial load and shaft resistance profiles can be postulated (BourneWebb et al., 2009, 2012). In the following sections, the effects of the surrounding ground and the end restraints on the behaviour of pile are discussed separately for clarity.

\section{Influence of pile-soil interface resistance}

When a heating cycle is applied to a pile it expands, and any axial deformation will be opposed by shaft restraint at the pile-soil interface. If both ends are free to move, and assuming that the shaft restraint to thermal response is constant with depth, this will result in minimum $\varepsilon_{\mathrm{T}-\mathrm{Obs}}$ at mid-depth, and maxima at the ends. The axial strain profiles for different degrees of shaft restraint resulting from thermal expansion of the pile are shown in Fig. 2(a). Two different cases are considered to illustrate the impact of ground resistance on pile behaviour: Profile A (strong shaft resis- 


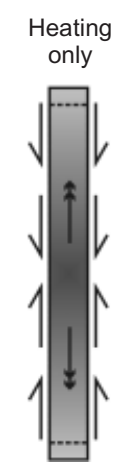

$$
\text { Profile A: }
$$

$$
\text { strong ground }
$$$$
\text { resistance }
$$

\section{Profile B:}

weak ground

resistance
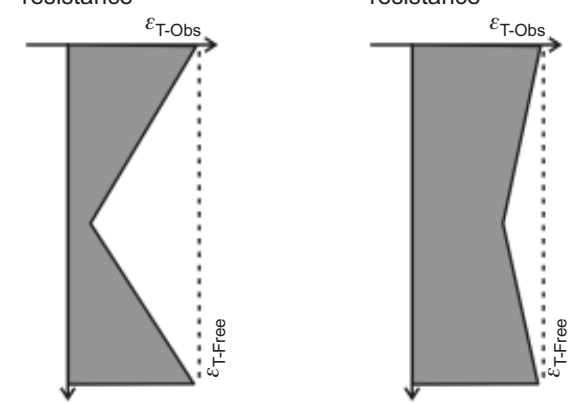

(a)
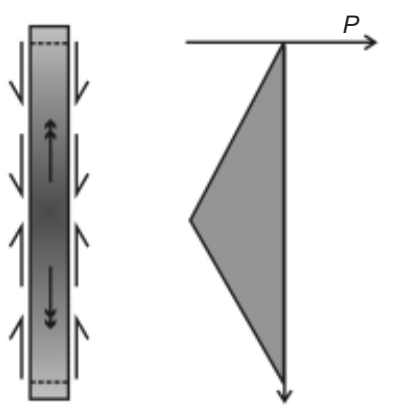

(b)
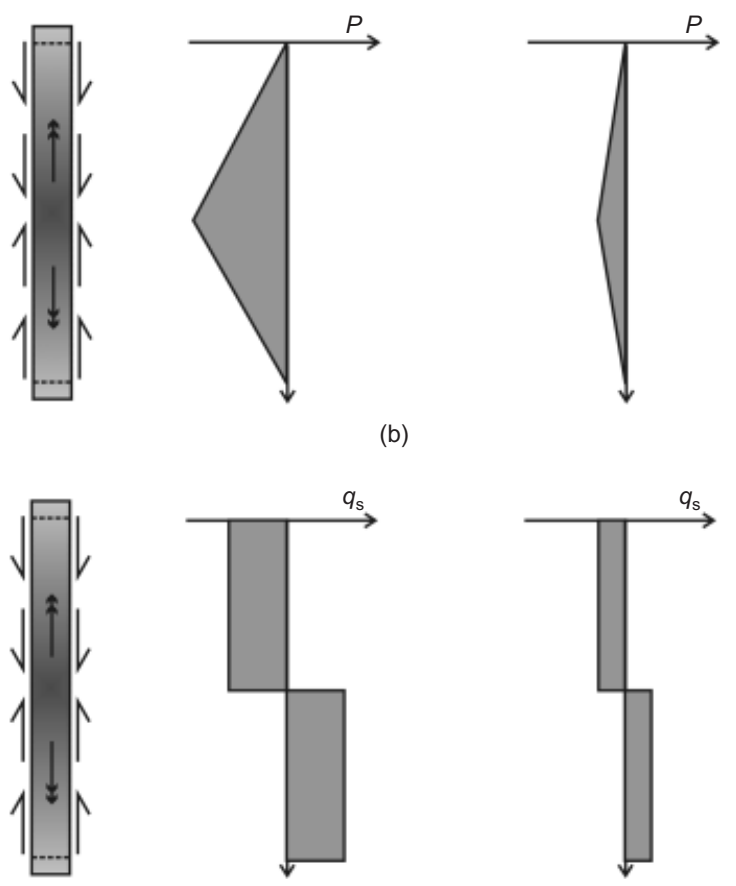

(c)

Fig. 2. Effect of thermal loading and surrounding ground on pile behaviour during heating with no end restraint (after BourneWebb et al., 2012): (a) axial thermal strain profiles; (b) axial thermal load profiles; (c) thermally mobilised load profiles

tance) and Profile B (weak shaft resistance). The minimum value of $\varepsilon_{\mathrm{T}-\mathrm{Obs}}$ is expected to reduce with increasing interface resistance and depends on a number of factors including the type of ground (clayey, granular), ground stiffness and the magnitude of thermal input.

The restraint provided at the pile-soil interface generates thermally induced axial load, which is compressive when the pile is heated, and can be computed using equation (4). For the axial strain profile shown in Fig. 2(a), the restrained strain $\varepsilon_{\mathrm{T}-\mathrm{Rstr}}$ and the axial load $P_{\mathrm{T}}$ will be largest at mid-depth (Fig. 2(b)). These expansive deformations generate a 'negative' shaft friction (the pile expands up relative to the surrounding soil) over the upper half of the pile and a 'positive' shaft friction (pile pushes down) over the lower half (Fig. 2(c)).

If cooled, the pile will contract (negative axial strain), generating tensile axial load, positive shaft friction over the upper half and negative shaft friction over the lower half of the pile. Thus the basic shape of the profiles remains the same, but the sign is the reverse of that for the heating cycle.

\section{Influence of pile end restraint}

End restraint can be provided by the superstructure and associated loading at the pile head, and also by the presence of a stiff bearing layer at the pile toe. Pile installation has a great influence on the geotechnical performance of energy piles. For instance, the quality of cleaning the pile base before placing concrete has an influence on the end restraint of an energy pile (Brandl, personal communication, 2011). During heating, if any restraint is imposed on the pile ends, expansive strains will be restricted and additional compressive load developed. The resultant strain and hence the load profile will vary, depending on the relative stiffness of the end restraint, and this is illustrated by the three profiles shown in Fig. 3: Profile $C$ (partial restraint at the top and the toe); Profile D (no restraint at the top and restraint at the toe); and Profile E (restraint at the top and no restraint at the toe). When both end restraints are strong, the magnitude of the additional axial load will be large, but the variation in axial load along the shaft is likely to diminish, because relative movement on the pile-soil interface is suppressed. Upon cooling, the reverse effect will occur: that is, the axial stress becomes tensile.

\section{Verification of mechanisms of response}

To validate the mechanisms shown in Figs 2 and 3, data from the London heat sink pile and the Lausanne T- 1 test are considered here. In the London case, at day 35 the imposed temperature change $(\Delta T)$ relative to initial ambient conditions $\left(T_{0} \sim 18^{\circ} \mathrm{C}\right)$ was $+29 \cdot 4^{\circ} \mathrm{C}$. A cooling phase lasting until day 47 followed, and two daily heating and cooling cycles completed the thermal loading, as shown in Fig. 4. In this paper, only the behaviour of the pile during the first heating cycle is discussed. In the Lausanne case, the pile temperature peaked at $34 \cdot 8^{\circ} \mathrm{C}\left(\Delta T=+20 \cdot 9^{\circ} \mathrm{C}\right)$ on day 12 of test $\mathrm{T}-1$, and then the pile was left to cool naturally until day 28, as shown in Fig. 4. Except for the uppermost few metres, where surface air temperatures have some effect, the temperature profiles are effectively uniform along the piles (Laloui et al., 2003; Amis et al., 2008).

\section{Thermal axial strain response}

In the London case, the effect of thermal changes on the axial deformation can be demonstrated from the observed strain ( $\left.\varepsilon_{\mathrm{T}-\mathrm{Obs}}\right)$ profile at $\Delta T=+29 \cdot 4^{\circ} \mathrm{C}$, as shown in Fig. 5(a). During heating, the maximum strain occurred at the ends, whereas the minimum strain occurred at about middepth. The free thermal strain $\left(\varepsilon_{\mathrm{T}-\text { Free }}\right)$ profile, as if there is no soil restraint, is also shown. A comparison of the measured strain profile and the free thermal strain profile shows that almost $100 \%$ strain is mobilised at the ends, while about $50 \%$ strain is mobilised at mid-depth. This is comparable to Profile A in Fig. 2(a).

In contrast, in the Lausanne T-1 test, a significant amount of strain change was observed throughout the depth of the pile by the change in temperature of $\Delta T=+20 \cdot 9^{\circ} \mathrm{C}$, as shown in Fig. 5(b). The strain mobilised was more than $70 \%$ of the free thermal strain. The location of the minimum strain is at around $20 \mathrm{~m}$ depth. Thermal expansion was resisted by both shaft and end restraint. The toe did not move as freely as the top, and hence the influence of the end resistance offered by the sandstone can be observed. The mechanism for the T-1 Lausanne case is comparable to Profile D in Fig. 3.

\section{Thermally induced axial load/stress}

Axial load profiles for the two cases were computed from the axial strain profiles using equation (4), as shown in Fig. 6. The London heat sink pile exhibits a triangular load profile with near-zero thermally induced load at the two 

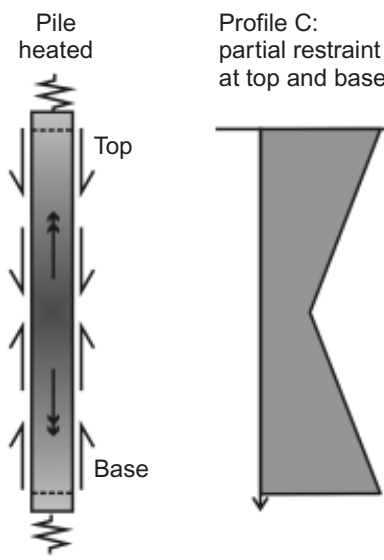

Profile D:

no restraint at top,

strong at base

Profile E:

strong restraint at

top, none at base
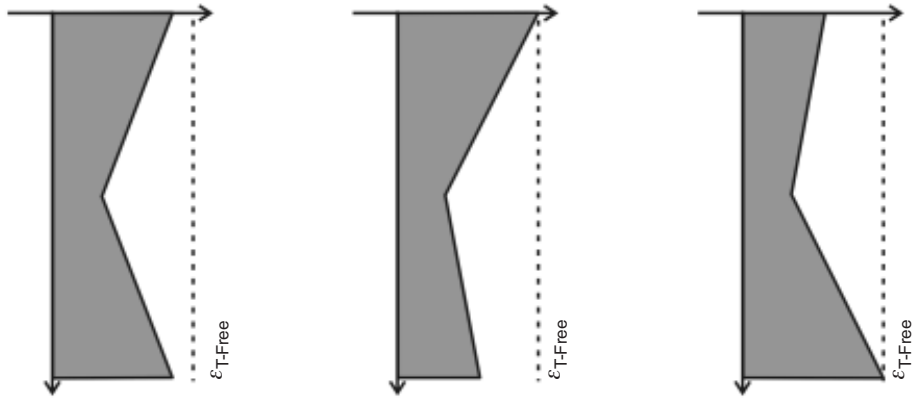

(a)
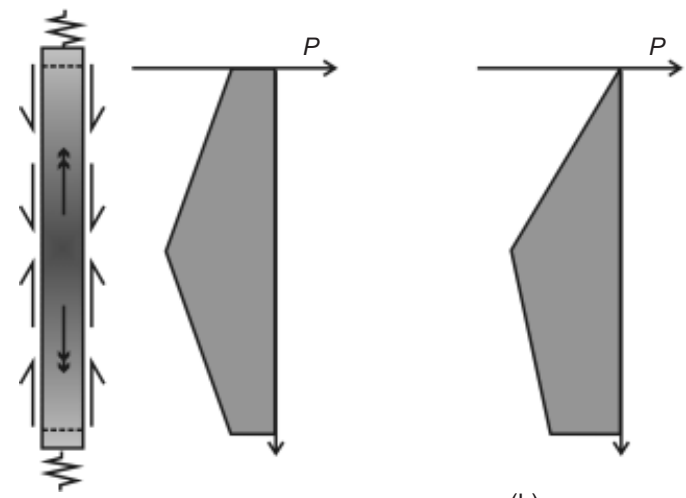

(b)
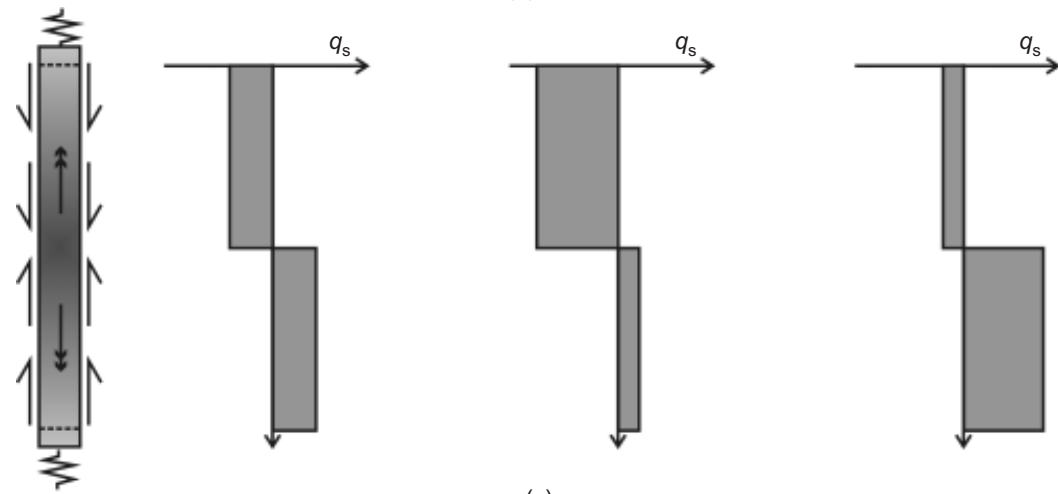

(c)

Fig. 3. Effect of thermal loading and surrounding ground on pile behaviour during heating with end restraint imposed (after Bourne-Webb et al., 2012): (a) axial thermal strain profiles; (b) axial thermal load profiles; (c) thermally mobilised load profiles

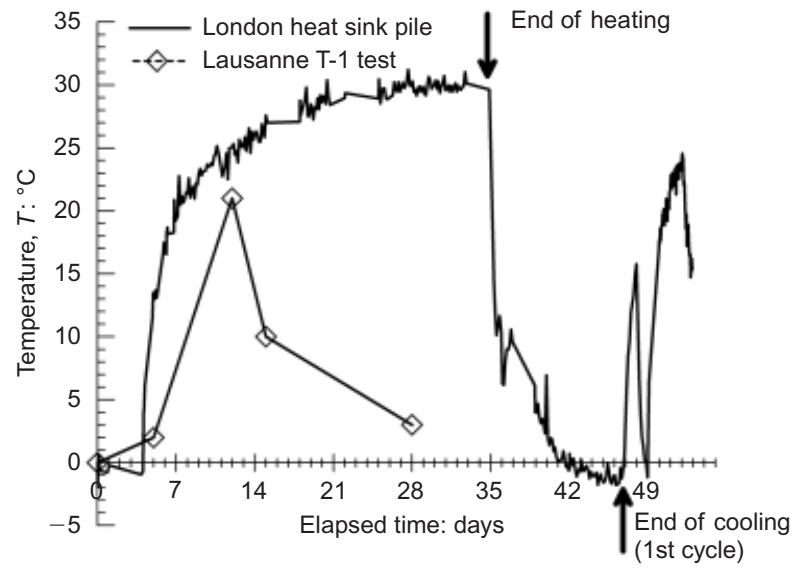

Fig. 4. Pile average temperature variation during tests ends, indicating that the end restraint is negligible (see Fig. 6(a)). A maximum axial compressive load of about $1550 \mathrm{kN}$ was developed slightly below the mid-depth point in response to heating of $+29 \cdot 4^{\circ} \mathrm{C}$. As a consequence of increasing soil resistance with depth, the pile's expansion mobilised greater shaft resistance over the lower section, and thus the neutral point for forces in the pile was drawn downwards.

In the Lausanne case, thermally induced load was developed at the toe (see Fig. 6(b)), which was founded on the sandstone layer. At the head, a small axial load resulted from the restraint of the pile raft slab that had been constructed at this stage. An axial compressive load of about $2150 \mathrm{kN}$ was developed in the lower half of the pile in response to a temperature increase of $+20 \cdot 9^{\circ} \mathrm{C}$.

The variation of thermally induced axial stress $\sigma_{\mathrm{a}}$ with temperature change is examined in Fig. 7. Data are taken from the level where the induced stress was highest $(17 \mathrm{~m}$ in 


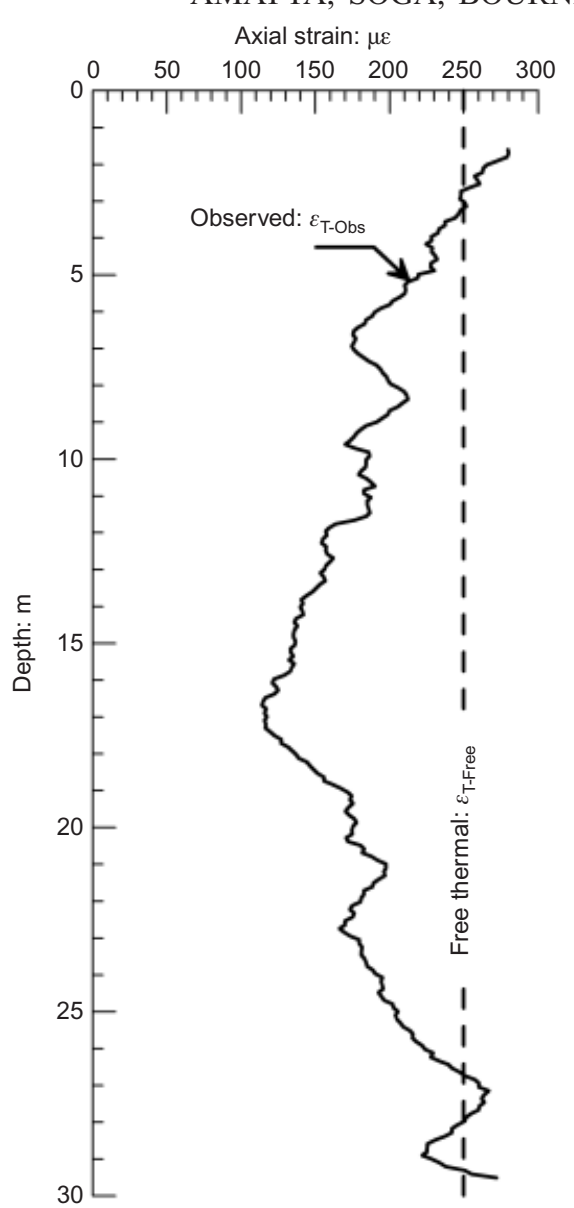

(a)

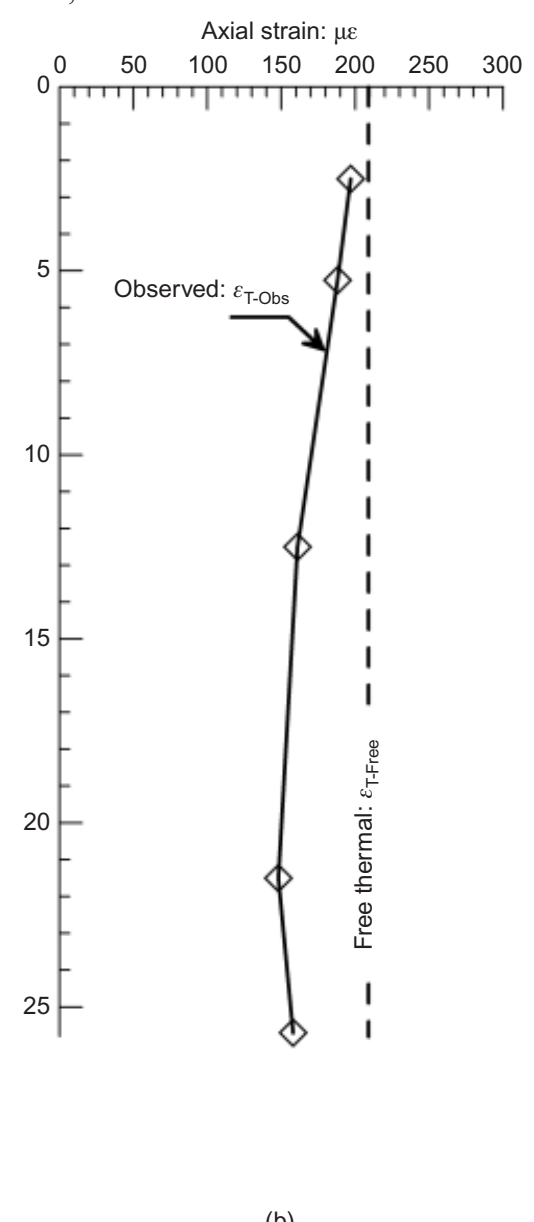

(b)

Fig. 5. Observed and free thermal strain profiles due to heating: (a) London heat sink pile, $\Delta T=29 \cdot 4^{\circ} \mathrm{C}$; (b) Lausanne test $\mathrm{T}-1, \Delta T=20.9^{\circ} \mathrm{C}$

the heat sink pile and $21.5 \mathrm{~m}$ in the $\mathrm{T}-1$ test), with additional data from the head and toe of the Lausanne pile. In both cases, an approximately linear increase in axial stress with temperature is observed. If the piles had been perfectly restrained against thermal deformation, the theoretical stress change would have been $-340 \mathrm{kPa} /{ }^{\circ} \mathrm{C}$ and $-292 \mathrm{kPa} /{ }^{\circ} \mathrm{C}$ for the London and Lausanne cases respectively. The observed maximum rate of increase in axial stress was $-192 \mathrm{kPa} /{ }^{\circ} \mathrm{C}$ $\left(56 \%\right.$ of maximum) for the London case and $-104 \mathrm{kPa} /{ }^{\circ} \mathrm{C}$ $(36 \%)$ for the Lausanne case. Clearly, the piles are not perfectly restrained against thermally induced deformation.

In the Lausanne case, the expanding pile is forced to focus its movement upwards, owing to the stiff sandstone at its toe, resulting in the development of axial stress that is larger over the bottom half of the pile than over the upper half of the pile. The raft connected to the pile head also provided some end restraint, causing an axial stress response. The rate of increase in compressive axial stress was about $-87 \mathrm{kPa} /{ }^{\circ} \mathrm{C}(30 \%$ of maximum $)$ at the toe and $-50 \mathrm{kPa} /{ }^{\circ} \mathrm{C}(17 \%)$ at the top of the pile.

Shaft resistance changes resulting from thermal load

In response to heating and pile movements, in both cases 'negative' shaft friction developed over the upper part of the pile and positive over the lower, as shown in Fig. 8, approximating Profile A in Fig. 2(c) for the London case and Profile D in Fig. 3(c) for the Lausanne test. In the London case (Fig. 8(a)) an average resistance of about $-50 \mathrm{kPa}$ developed over the upper $17 \mathrm{~m}$ and about $75 \mathrm{kPa}$ over the lower $13 \mathrm{~m}$ of the pile shaft. The difference in the two values may be reflected by the gradual increase in strength of the ground with depth. The mobilised values were still below the expected ultimate average shaft resistance of $120 \mathrm{kPa}$, which was extrapolated from a destructive load test (Bourne-Webb et al., 2009).

In the Lausanne case (Fig. 8(b)), shaft resistance changed by about $-50 \mathrm{kPa}$ in the $12 \mathrm{~m}$ thick soft clay deposit. However, in the soft clayey till deposits on the lower shaft (12$21.5 \mathrm{~m} \mathrm{depth})$, very little change in shaft resistance was apparent. The shaft resistance in the bottom stiff till (21.5$25 \mathrm{~m}$ depth) increased to $19 \mathrm{kPa}$. Although the detailed pile-soil interaction is complicated by the layered soil conditions, the shaft resistance profile is comparable to that shown in Fig. 3(c): Profile D.

The change in mobilised average shaft resistance associated with temperature change is illustrated in Fig. 9. The values were taken over sections of pile shaft, as noted in the figure. The absolute change in mobilised shaft resistance increases approximately linearly with temperature, with values of $2 \cdot 1-2 \cdot 5 \mathrm{kPa} /{ }^{\circ} \mathrm{C}$ in the London Clay case. In the Lausanne case, it is $1.5 \mathrm{kPa} /{ }^{\circ} \mathrm{C}$ in the soft alluvial clay (5-12 $\mathrm{m}$ depth), $0.5 \mathrm{kPa} /{ }^{\circ} \mathrm{C}$ in the soft till $(12-21.5 \mathrm{~m}$ depth) and $0.9 \mathrm{kPa} /{ }^{\circ} \mathrm{C}$ in the stiff till $(21.5-25 \mathrm{~m}$ depth).

\section{PILE-SOIL INTERACTION UNDER THERMO- MECHANICAL LOADING \\ Conceptual background}

When a load-bearing pile serves as a heat sink or source, the total mobilised strain $\varepsilon_{\text {Total }}$ at any depth can be estimated as 


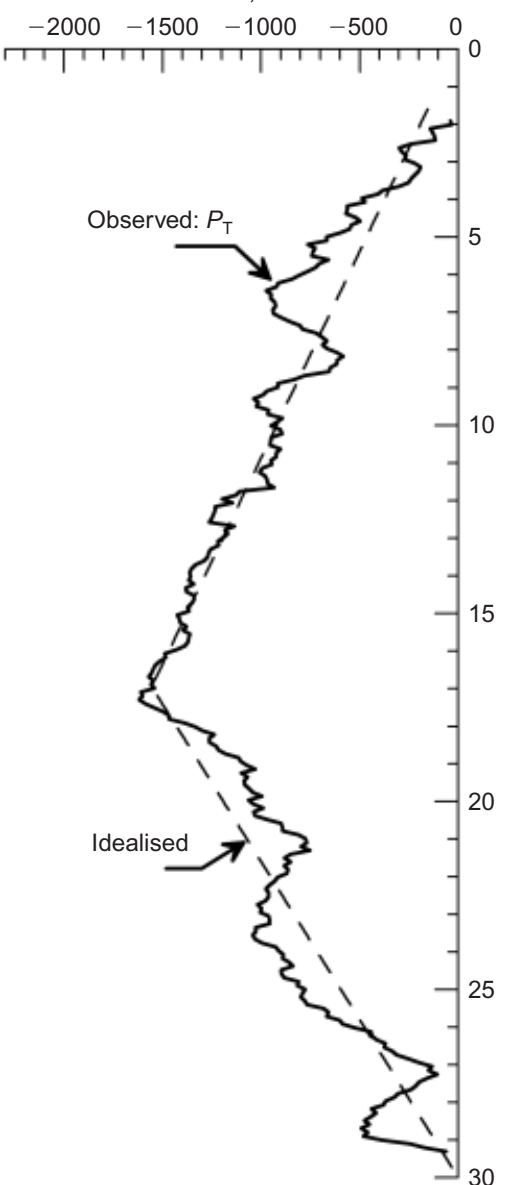

(a)

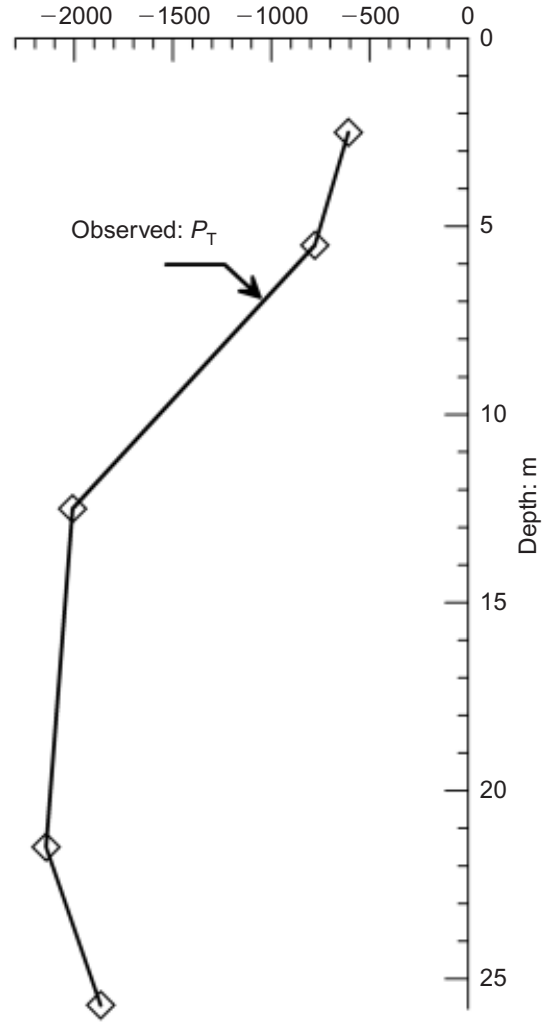

(b)

Fig. 6. Axial force profiles at end of heating: (a) London heat sink pile, $\Delta T=29 \cdot 4^{\circ} \mathrm{C}$; (b) Lausanne test $\mathrm{T}-1, \Delta T=20 \cdot 9^{\circ} \mathrm{C}$

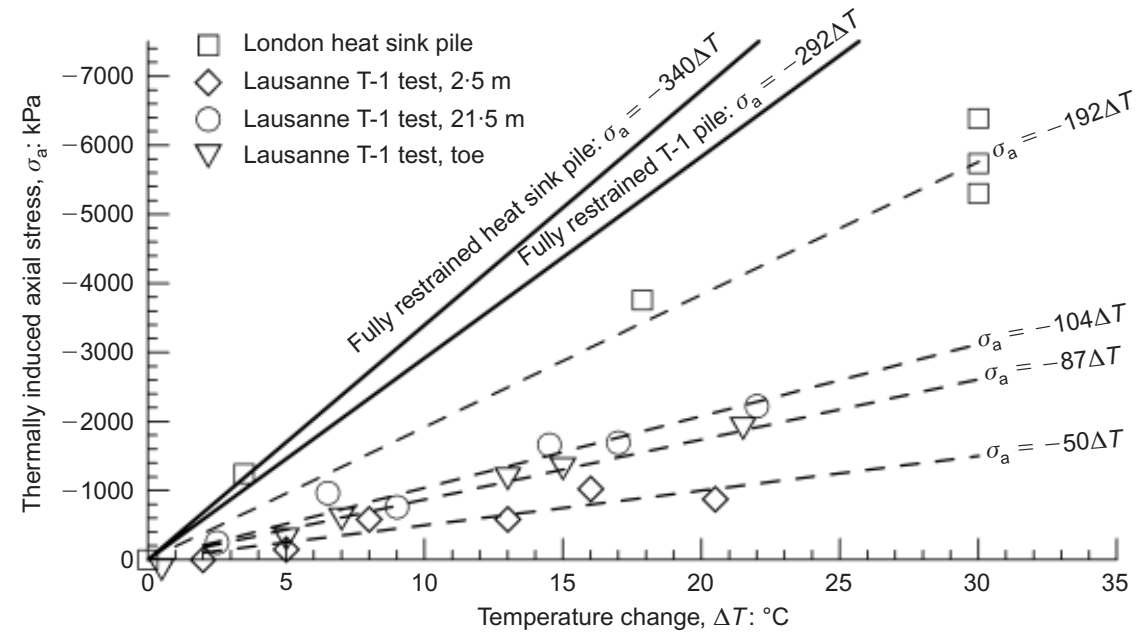

Fig. 7. Variation of pile axial stress when heated

$$
\varepsilon_{\text {Total }}=\varepsilon_{\mathrm{M}}+\varepsilon_{\mathrm{T}-\mathrm{Obs}}
$$

where $\varepsilon_{M}$ is the mechanical strain imposed in the pile due to loading at the pile head, and $\varepsilon_{\mathrm{T}-\mathrm{Obs}}$ is the strain due to thermal changes. The mechanical strain $\varepsilon_{M}$ is directly developed due to a mechanical load $\left(P_{\mathrm{M}}\right)$

$$
P_{\mathrm{M}}=E A \varepsilon_{\mathrm{M}}
$$

Using $\varepsilon_{\mathrm{T}-\mathrm{Obs}}$ data, a restrained strain $\varepsilon_{\mathrm{T}-\mathrm{Rstr}}$ (equation (3)) can be deduced, which gives the axial thermal load $P_{\mathrm{T}}$ (equation (4)). A combination of these two equations (equations (4) and (6)) gives the total load, $P_{\text {Total }}$

$$
P_{\text {Total }}=P_{\mathrm{M}}+P_{\mathrm{T}}
$$

Simplified axial load and shaft resistance distribution diagrams are shown in Figs 10 and 11 (following Bourne-Webb et al., 2009, 2012), where the effect of mechanical load only, heating/cooling only and the combined effects of these two are considered. It is first assumed that the mechanical 


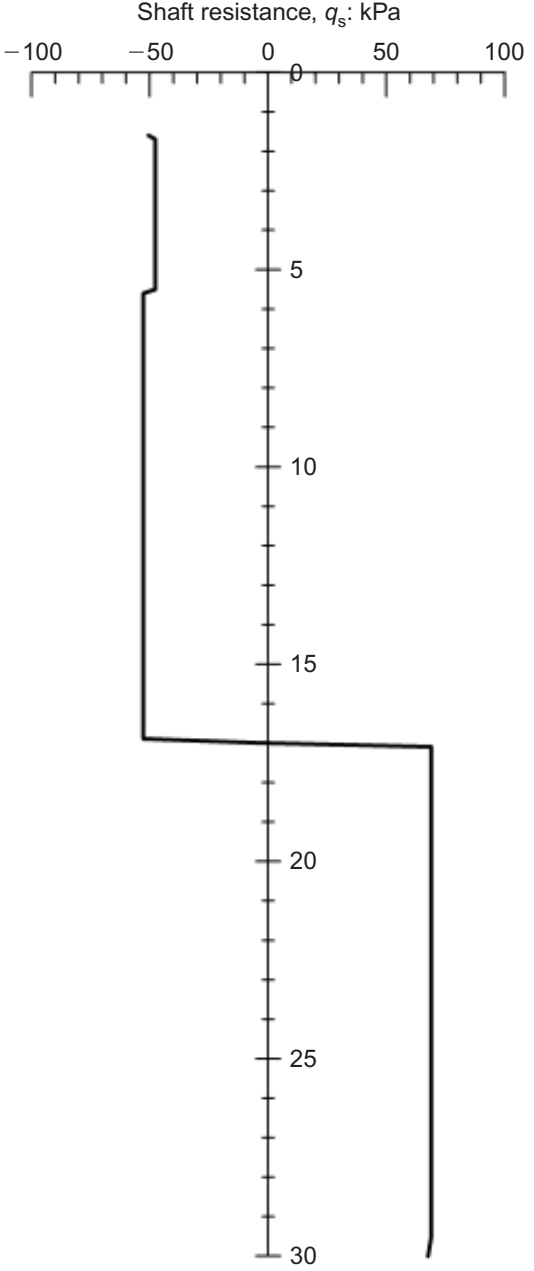

(a)

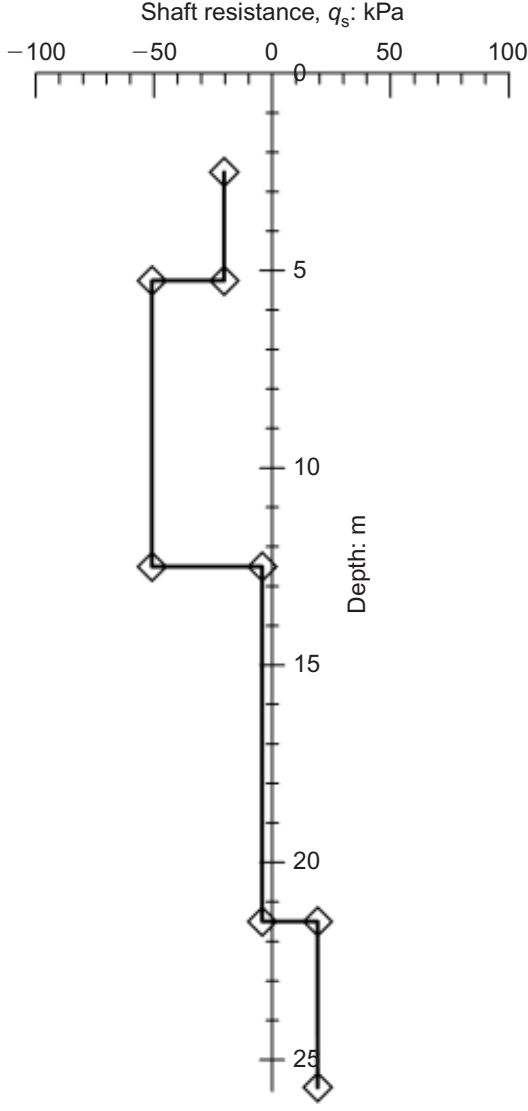

(b)

Fig. 8. Pile shaft friction mobilised in response to heating: (a) London heat sink pile, $\Delta T=29 \cdot 4^{\circ} \mathrm{C}$; (b) Lausanne test $\mathrm{T}-1, \Delta T=20 \cdot 9^{\circ} \mathrm{C}$

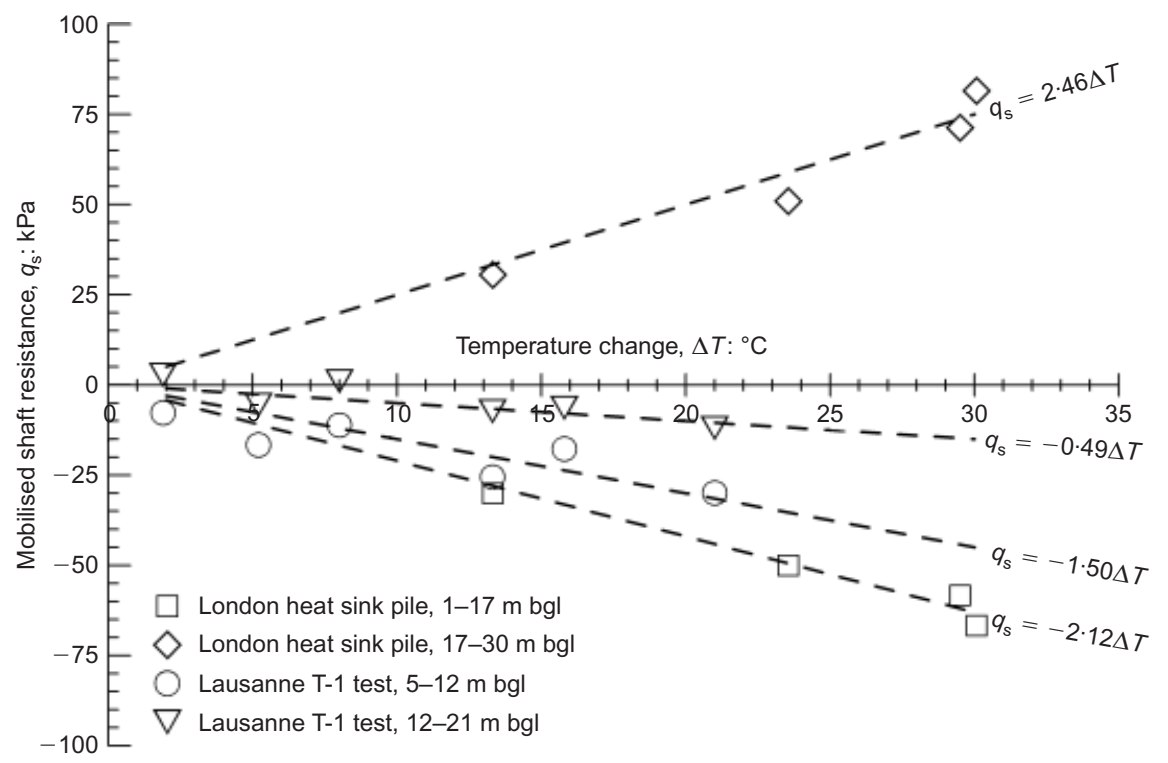

Fig. 9. Variation of mobilised shaft friction during heating

load is resisted by the mobilised shaft resistance only, and that such resistance is uniform along the length of the shaft, that is, constant rate of change in axial load with depth, as shown in Fig. 10(a). Subsequent figures illustrate pile response to thermal load only: that is, cooling (Fig. 10(b)) and heating (Fig. 10(d)), and combined thermo-mechanical loading (Figs 10(c) and Fig. 10(e)). These diagrammatic descriptions of pile response can be extended to illustrate 

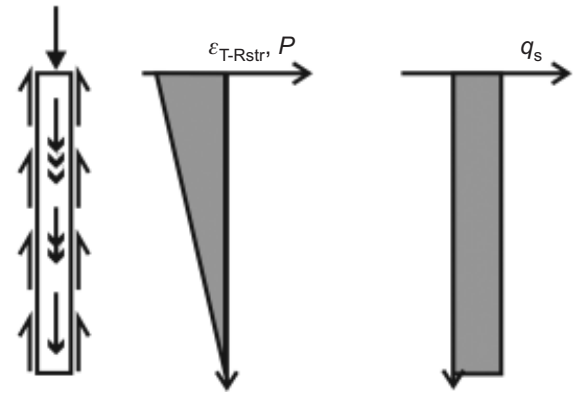

$c=$ axial strain in pile

$P=$ axial load in pile $(=\varepsilon . A E)$

$q_{\mathrm{s}}=$ pile/soil interface shear stress

$A=$ pile cross-sectional area

$E=$ pile elastic modulus

(a)
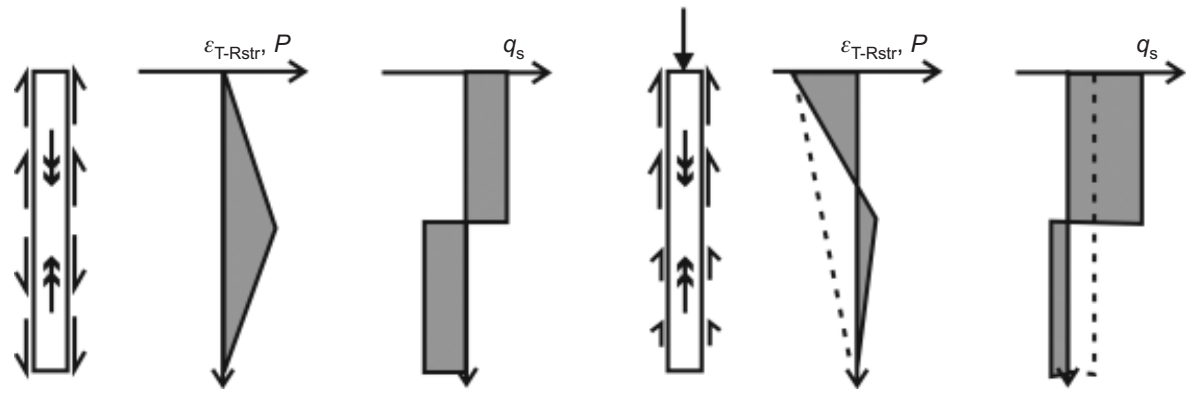

(b)

(c)

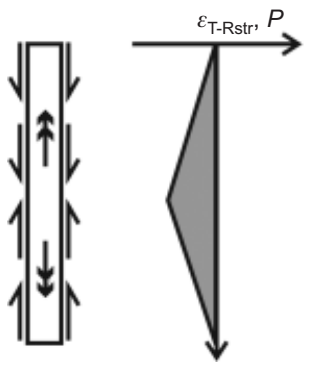

(d)
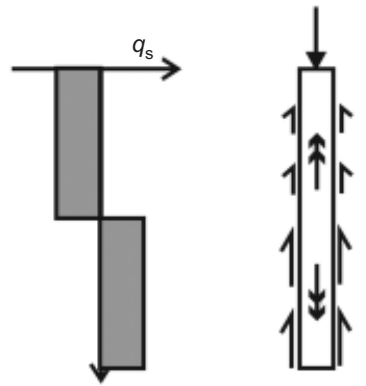

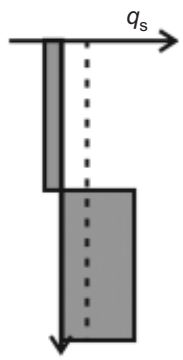

(e)

Fig. 10. Response mechanism for pile undergoing thermo-mechanical loading; heating and cooling with no end restraint (after Bourne-Webb et al., 2009, 2012): (a) load only; (b) cooling only; (c) combined load and cooling; (d) heating only; (e) combined load and heating

the effect of end restraint as shown in Fig. 11, where Profile C (Fig. 11(a)) and Profile E (Fig. 11(c)) from Fig. 3 consider heating in combination with mechanical loading. The restrained ends prevent the pile from expanding freely when heated, which leads to the generation of additional axial load, and the total axial load increases, as shown in Figs 11(b) and 11(d).

\section{Verification of mechanisms of response}

In the London case, the variation of temperature of the main test pile at mid-depth during the duration of the test is shown in Fig. 12(a). With an imposed load of $1200 \mathrm{kN}$, the pile was first cooled (the reverse of the heat sink pile) for 35 days, and then heated for 12 days. Two more temperature cycles lasting a day each were then applied (not considered in this paper). The average temperature at the end of the first cooling cycle (i.e. on the 35 th day) was about $-1{ }^{\circ} \mathrm{C}$ $\left(\Delta T \sim-19^{\circ} \mathrm{C}\right)$, whereas at the end of the subsequent heating cycle (i.e. on the 47 th day) it was about $+28^{\circ} \mathrm{C}$ $\left(\Delta T \sim+10^{\circ} \mathrm{C}\right)$; except for a few metres close to the ground surface, temperature change is uniform over the full depth of the pile, as shown in Fig. 13(a).

In the Lausanne case, seven thermal loading tests (T-1 to T-7) were performed. In each phase of testing, the test pile was first heated over about two weeks, and then it was allowed to recover and equilibrate with the ambient ground temperature over about another two weeks. All tests following T-1 were performed in combined thermo-mechanical loading conditions; tests T-6 and T-7 are examined here, and in both, the imposed mechanical load was significant (1183 kN and $1088 \mathrm{kN}$ respectively) as the building was nearing completion. The temperature of the pile at around mid-depth for the whole test series is presented in Fig. 12(b), and the profiles of temperature change, at the end of heating during tests T-6 and T-7, are shown in Fig. 13(b). The average temperature increase in the pile was $17 \cdot 8^{\circ} \mathrm{C}$ and $18 \cdot 0^{\circ} \mathrm{C}$ for $\mathrm{T}-6$ and $\mathrm{T}-7$ respectively, and the temperature profiles were uniform. Pile temperature after a thermal recovery cycle was always slightly higher than the initial temperature in each test phase, indicating a build-up of thermal mass around the test pile.

In the Bad Schallerbach case, because of the way the data were collected, the pile response is examined over an interval of about 2 years, during which the pile was used primarily as a heat source. Fig. 12(c) shows the variation of temperature with time at three levels in the pile, whereas Fig. 13(c) shows the temperature change profile in the pile between February 1996 and February 1998. The mixture of warming at the top, possibly from the floor slab, and cooling at depth makes the assessment of the pile response more complicated than in the other cases. 

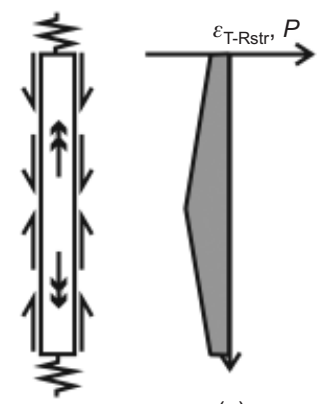

(a)
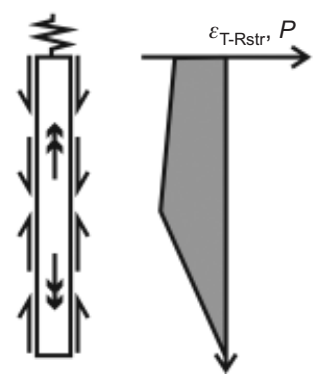

(c)
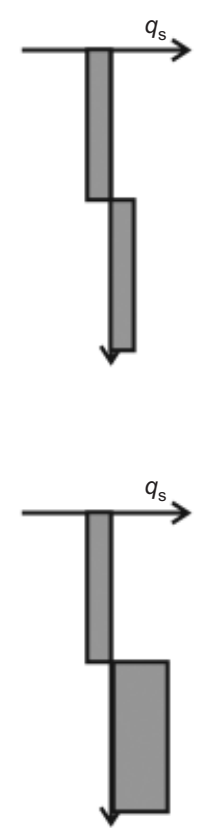

$\stackrel{q_{\mathrm{s}}}{\rightarrow}$
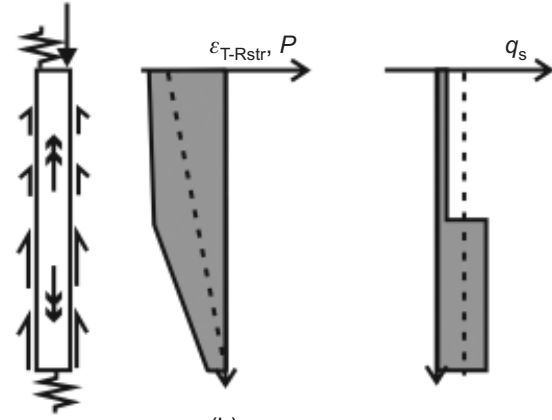

(b)
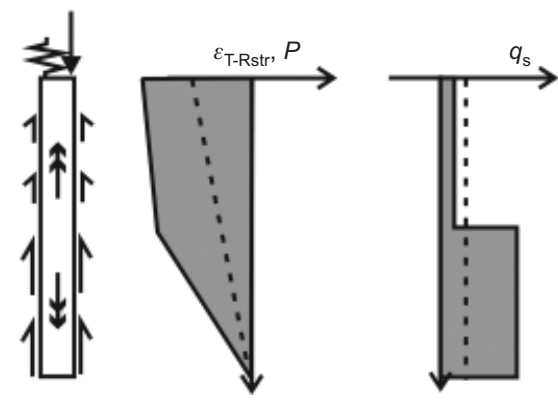

(d)

Fig. 11. Response mechanism for pile undergoing thermo-mechanical loading; heating and cooling with end restraint (after Bourne-Webb et al., 2009, 2012): (a) both ends partially restrained; (b) combined load and heating; (c) top restrained and toe unrestrained; (d) combined load and heating

\section{Axial strain response}

Measured axial strain profiles are shown in Fig. 14(a) for the London case and Fig. 14(b) for the Lausanne case. The strain profiles for the mechanical load only $\left(\varepsilon_{M}\right)$ were obtained before any thermal loading, whereas those for the combined loading $\left(\varepsilon_{\text {Total }}\right)$ were obtained at the end of a thermal cycle. The strain profile due to the thermal loading effect alone $\left(\varepsilon_{\mathrm{T}-\mathrm{Obs}}\right)$ is obtained by taking the difference of the two profiles. The data from both cases show that the mechanical strain due to the building load $\left(\varepsilon_{\mathrm{M}}\right)$ decreases with depth, owing to shaft resistance, and that the mobilised end-bearing is small.

In the London case, the pile contracted during the initial cooling phase; the measured total stain becomes more compressive, with strain values becoming less so with depth, as shown in Fig. 14(a-i). Before cooling, pile head settlement was $2.41 \mathrm{~mm}$ owing to the mechanical loading only. At the end of cooling, the total pile settlement was $4.76 \mathrm{~mm}$, indicating an additional settlement of $2.35 \mathrm{~mm}$ by the thermal loading (Bourne-Webb et al., 2009). The thermally induced strain $\varepsilon_{\mathrm{T}-\mathrm{Obs}}$ profile lies to the right of the free strain $\varepsilon_{\text {T-Free }}$ profile, implying tensile-restrained strains $\varepsilon_{\mathrm{T}-\mathrm{Rstr}}$.

During heating, the pile expanded and total strain became less compressive, with tensile values developing towards the toe of the pile, as shown in Fig. 14(a-ii). The pile-head settlement at the end of heating was $3.13 \mathrm{~mm}$, producing a heave of $1.63 \mathrm{~mm}$ from the cooling stage. The thermal strain $\varepsilon_{\mathrm{T}-\mathrm{Obs}}$ profile lies to the left of the free strain $\varepsilon_{\mathrm{T} \text {-Free }}$ profile, implying compressive restrained strains $\varepsilon_{\mathrm{T}-\mathrm{Rstr}}$. Further comparison of these profiles with the free strain profiles suggests that the toe and the head of the pile deformed freely during both cooling and heating.

In the Lausanne case, significant thermal expansion occurred compared with the compressive strains produced by the mechanical load. At the end of heating, tensile $\varepsilon_{\text {Total }}$ strain was measured along the length of the pile, as shown in Fig. 14(b). The thermally induced strain $\varepsilon_{\mathrm{T}-\mathrm{Obs}}$ profile induced by heating suggests that the toe expanded more than the pile head: that is, the offset to the free strain $\varepsilon_{\text {T-Free }}$ profile is less, indicating that the restraint imposed by the superstructure was greater. At the toe, $\varepsilon_{\mathrm{T} \text {-Obs }}$ was about $73 \%$ of $\varepsilon_{\text {T-Free }}$ (a value very similar to the $76 \%$ seen at the toe in test $\mathrm{T}-1$, when there was no building load), while at the top the ratio was about $42 \%$ (nearly $100 \%$ in $\mathrm{T}-1$ ). Compared with test $\mathrm{T}-1$, the $\varepsilon_{\mathrm{T}-\mathrm{Obs}}$ profiles in tests $\mathrm{T}-6$ and $\mathrm{T}-7$ are further to the left of the $\varepsilon_{\mathrm{T} \text {-Free }}$ profiles and thus the restrained strains $\varepsilon_{\mathrm{T}-\mathrm{Rstr}}$ and the associated thermal axial load $P_{\mathrm{T}}$ are larger.

In the Bad Schallerbach case, inconsistent thermal axial strain profiles are presented by Brandl (1998, 2006), which makes quantitative evaluation difficult. However, based on the load profiles presented later (Fig. 15(c)), it is likely that the toe moved freely while the head was restrained by the building superstructure.

\section{Thermally induced axial load response}

Using the measured strain data, axial load profiles for mechanical loading alone and combined thermo-mechanical loading are shown in Fig. 15. The net thermal effect, $P_{\mathrm{T}}$, is evaluated as the difference between the mechanical and total thermo-mechanical loads.

In the London case (Fig. 15(a)), the mechanical load profile $\left(P_{\mathrm{M}}\right)$ reveals axial load diminishing with depth; that most of the load is carried by shaft resistance. In the Lausanne case (Fig. 15(b)), the $P_{\mathrm{M}}$ profile over the upper section of the shaft is complex because of variations in the diameter of the pile (see Fig. 1(b)). However, the axial load in the pile shaft diminishes with depth and no base reaction is apparent, indicating a friction pile type response. In the Bad Schallerbach case, the imposed mechanical load was again carried largely on the pile shaft, as shown in Fig. $15(c)$.

The thermal load $\left(P_{\mathrm{T}}\right)$ profiles for both the cooling and heating cycles of the London test are approximately triangu- 

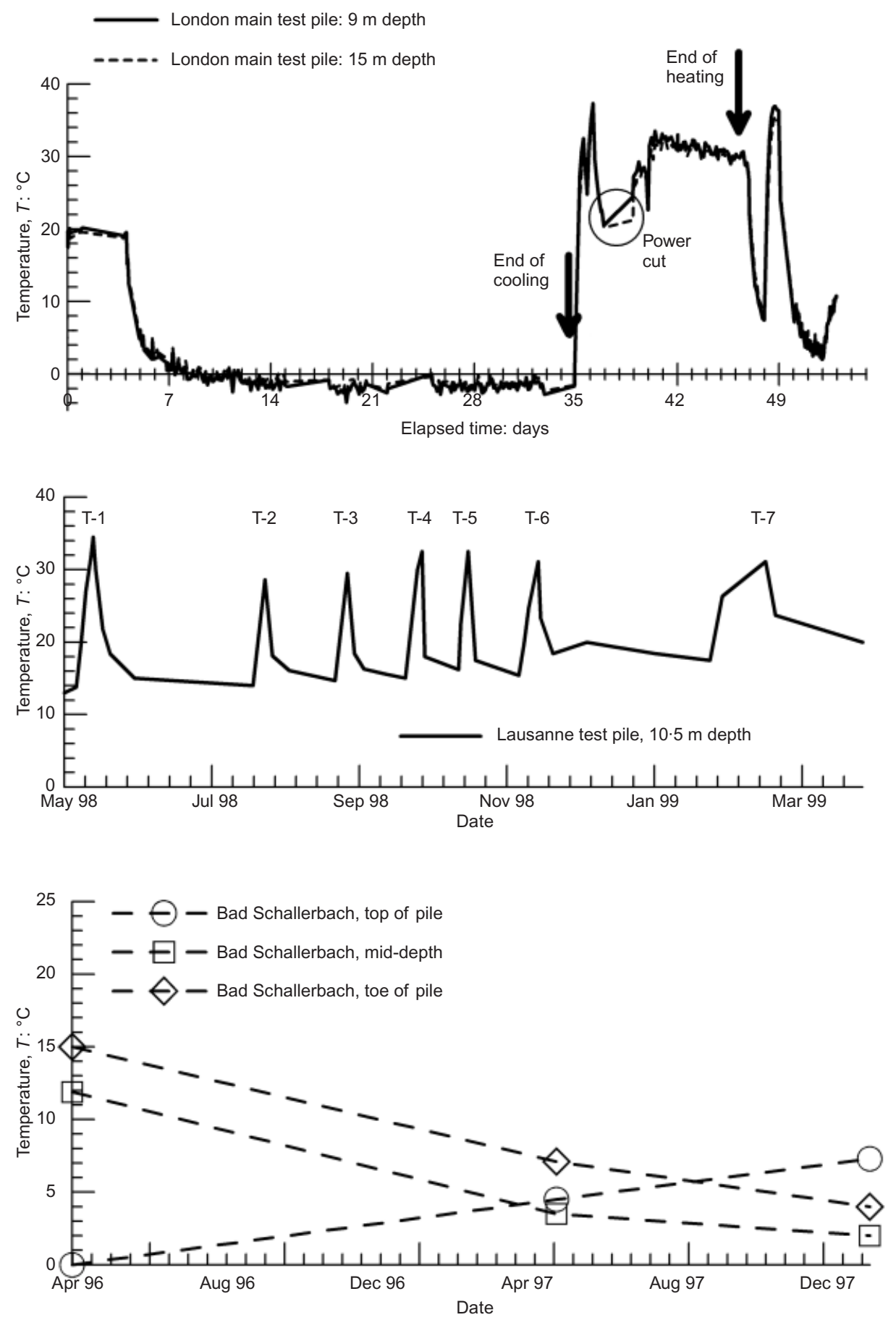

Fig. 12. Temperature variation during monitoring at the three sites

lar in shape, as shown in Fig. 15(a), and comparable to those in Figs 10(b) and 10(d). In the first cooling phase, with temperatures reduced by about $20^{\circ} \mathrm{C}$, a thermally induced tensile force of about $670 \mathrm{kN}$ was observed at $15 \mathrm{~m}$ depth, as shown in Fig. 15(a-i). As a result of this restraint of contraction of the shaft by the surrounding clay, the combined load profile shows tensile forces in the lower half of the pile, as shown in Fig. 15(a-i) and as illustrated in Fig. $10(\mathrm{c})$.

During the following heating phase, an increase in temperature of $10^{\circ} \mathrm{C}$ (relative to ambient conditions) resulted in a thermally induced compressive load of an additional $675 \mathrm{kN}$ at about $6.0 \mathrm{~m}$ depth, and a combined thermo-mechanical load of $1500 \mathrm{kN}$, as shown in Fig. 15(a-ii). This is comparable to the response suggested by Fig. 10(e). Notably, the location of the maximum load is not at the mid-depth of the pile, and moves up or down depending on the thermal phases. This is a function of the pile-soil interaction required to balance the forces that develop in the pile, whereby the head load remains constant and the reaction at the toe is effectively zero, and the variation in force in between is required to balance the forces induced by the thermal strain, which are a function of the resistance along the shaft.

The thermal loading $\left(P_{\mathrm{T}}\right)$ profile observed in the Lausanne tests was not triangular, as shown in Fig. 15(b). It is thought that the changes in the load profile from the triangular shape are due to end restraint effects, as proposed in Fig. 11(a). As a result of a partial restraint at the toe imposed by the sandstone layer and a strong restraint at the head imposed by the superstructure, a large thermal load was developed at both ends, as shown in Fig. 15(b). With additional shaft 


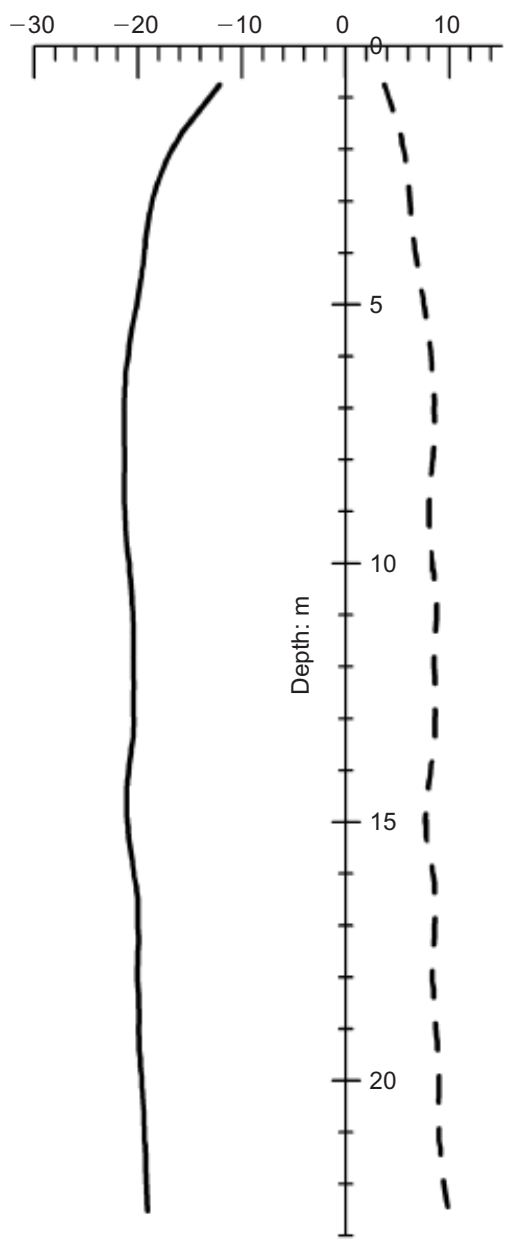

(a)
Temperature change, $\Delta T:{ }^{\circ} \mathrm{C}$

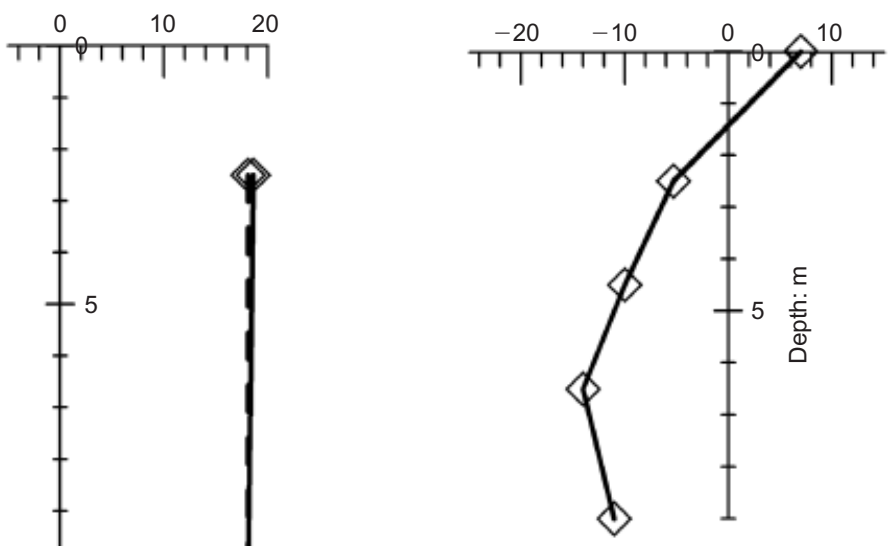

(c)

(b)
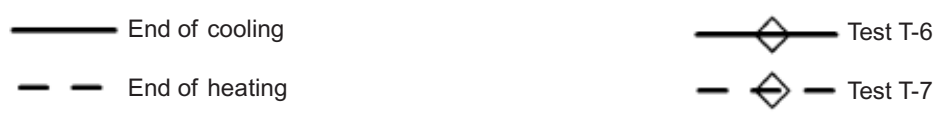

Fig. 13. Profile of temperature change in the test pile at each site: (a) London main test pile; (b) Lausanne tests

restraint, the maximum axial load is found at about $12.5 \mathrm{~m}$ depth. An increase in temperature of about $18^{\circ} \mathrm{C}$ yielded thermally induced compressive forces of $3060 \mathrm{kN}$ and $2830 \mathrm{kN}$ in tests $\mathrm{T}-6$ and $\mathrm{T}-7$ respectively; these are about $50 \%$ larger than in test $\mathrm{T}-1$. The associated maximum combined thermo-mechanical load was $3990 \mathrm{kN}$ and $3690 \mathrm{kN}$ for T-6 and T-7 respectively. Thermally induced loads at the pile head and toe were broadly similar in both tests, that is, averaging $2180 \mathrm{kN}$ and $1370 \mathrm{kN}$ for $\mathrm{T}-6$ and $\mathrm{T}-7$ respectively.

In the Bad Schallerbach case, the thermo-mechanical loading effect can be difficult to interpret, as the upper $1.5 \mathrm{~m}$ of the pile was warmed and the remaining length was cooled relative to the pile temperatures at the start of the monitoring interval, as shown in Fig. 13(c). The axial load profile due to mechanical load only was obtained in February 1996 (Brandl, 1998), as shown in Fig. 15(c). Two combined load profiles are shown: one presented directly by Brandl (1998), and one back-calculated from the shaft resistance profile also presented in Brandl (1998). Additional compressive load was developed over the upper $6.5 \mathrm{~m}$ of the pile, indicating that the pile head restraint was significant if the building load was constant. Close to the toe there was no additional thermal load, which could mean that the pile was free to contract by cooling at this location. The thermal axial load profile back-calculated from the shaft resistance suggests a stronger contraction of the pile than the former, and forces are seen to be tensile in the lower part of the shaft. If the simplified profiles presented in Figs 10(c) and 10(e) are combined for the corresponding warmed and cooled sections of the pile, a new load profile approximately similar to the observed profile can be derived, but it is difficult to assess the values quantitatively, owing to the nonuniform temperature profile.

\section{Axial stress changes}

The change in thermally induced stress with temperature for the London case is evaluated at three locations: $6 \mathrm{~m}$ depth, where the compressive stress was largest in the heating phase; $12 \mathrm{~m}$ depth, the mid-depth of the pile; and $15 \mathrm{~m}$ depth, where the tensile stress was largest in the 


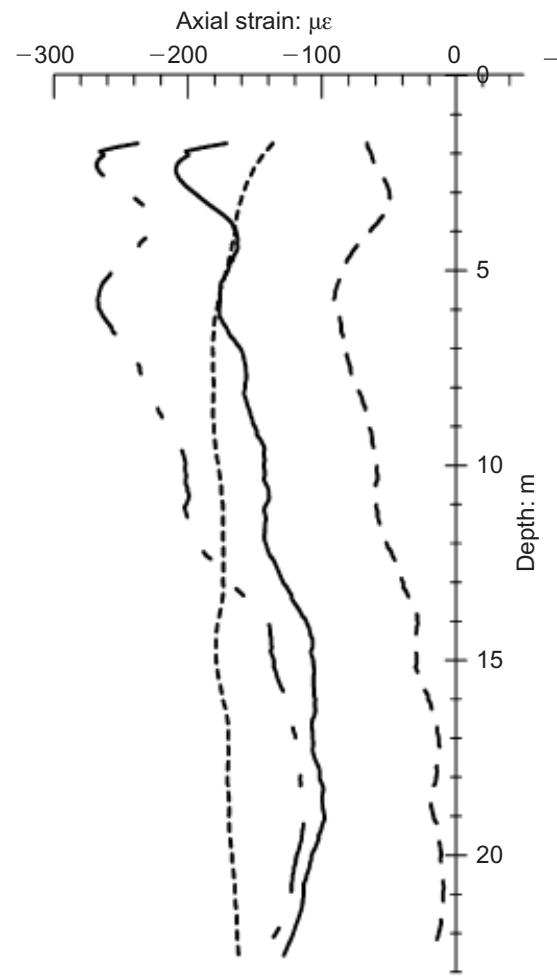

(i) Cooling, $\Delta T=-20^{\circ} \mathrm{C}$

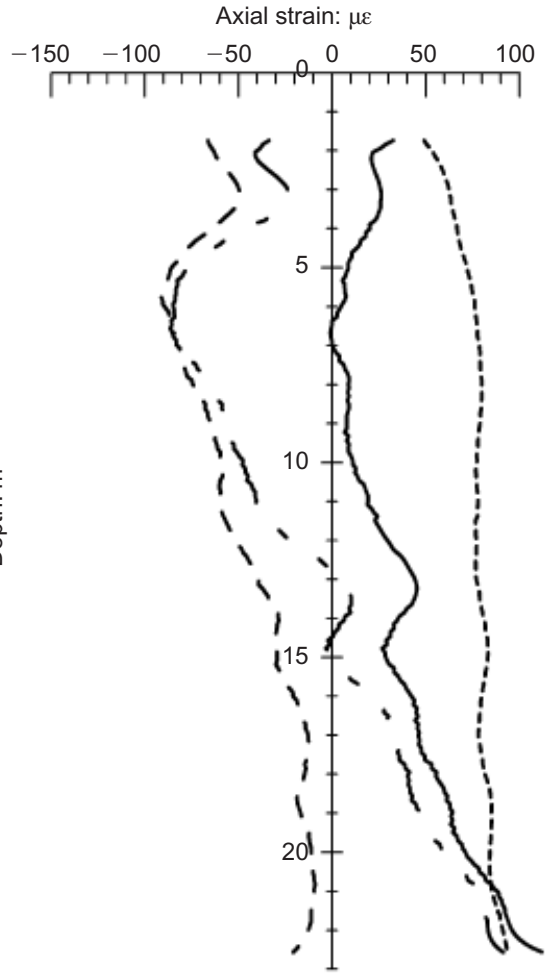

(ii) Heating, $\Delta T=+10^{\circ} \mathrm{C}$

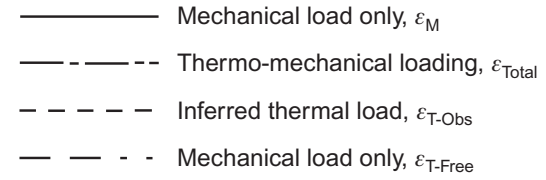

(a)

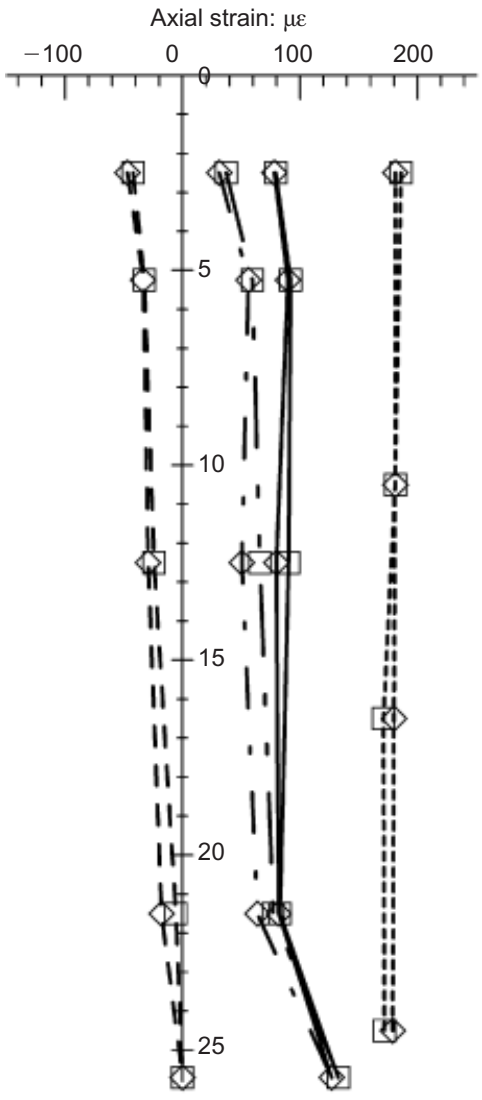

Heating, $\Delta T=+18^{\circ} \mathrm{C}$

$\diamond \mathrm{T}-6$ profiles

$\square$ T-7 profiles

(b)

Fig. 14. Measured axial strain profiles in: (a) London main test pile; (b) Lausanne tests T-6 and T-7

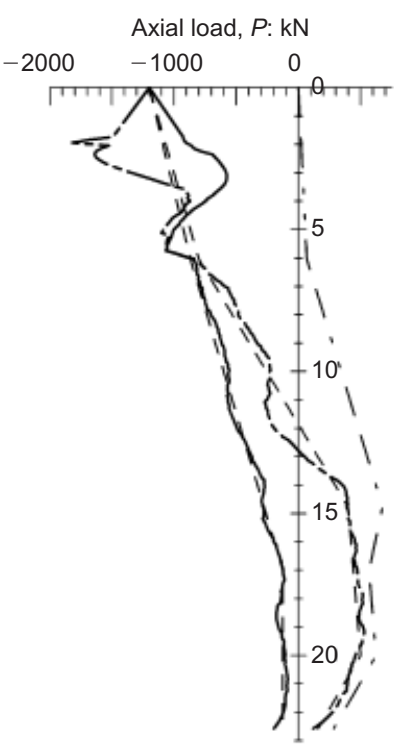

(i) Cooling, $\Delta T=-20^{\circ} \mathrm{C}$

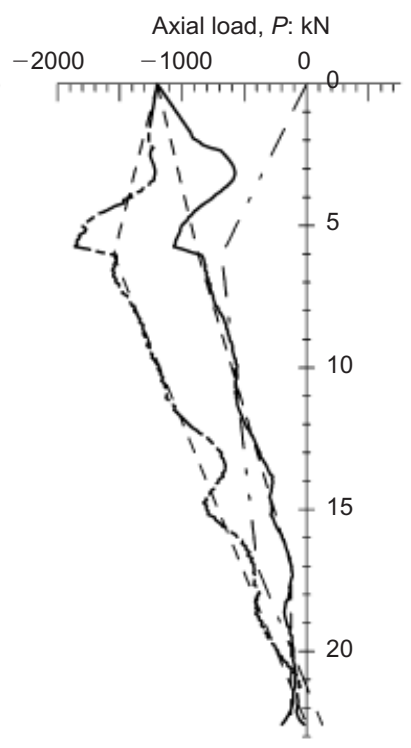

(ii) Heating, $\Delta T=+10^{\circ} \mathrm{C}$

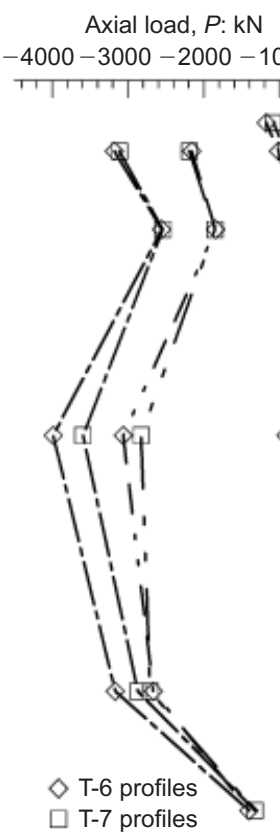

(b)

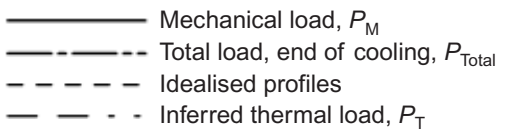

(a)
Axial load, $P: \mathrm{kN}$

Brandl (1998) skin friction $-15 \quad$ profile

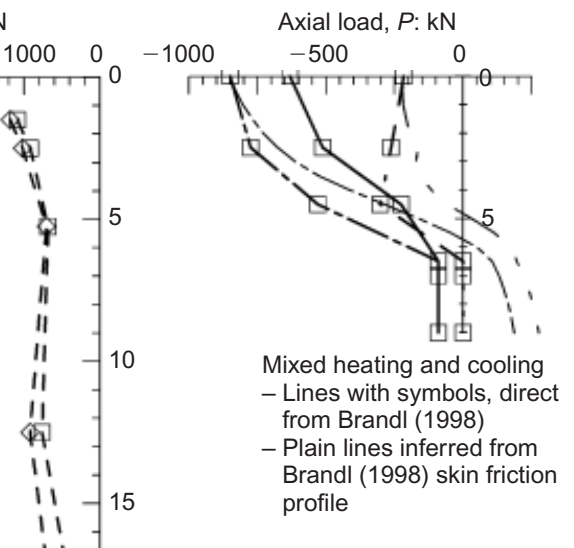

1

$11]$ 1 L 20 Q 15 I1 근 25 
cooling phase. For the Lausanne case, the stress was evaluated at four depths $-2.5 \mathrm{~m}$, mid-depth $(12 \mathrm{~m}), 21.5 \mathrm{~m}$ and the toe $(25.8 \mathrm{~m})$ - using data from $\mathrm{T} 1$ to $\mathrm{T} 7$. The axial stress-temperature relationships evaluated from the strain data are shown in Fig. 16, along with those for fully restrained conditions. For the Bad Schallerbach case insufficient data are available to allow this interpretation to be made.

During the heating phase, a unit degree change in temperature mobilised an additional axial stress within the pile of between $-261 \mathrm{kPa} /{ }^{\circ} \mathrm{C}$ ( $77 \%$ of fully restrained value) and $-329 \mathrm{kPa} /{ }^{\circ} \mathrm{C}(97 \%)$ in the London case, and $-147 \mathrm{kPa} /{ }^{\circ} \mathrm{C}$ $(50 \%)$ to $-153 \mathrm{kPa} /{ }^{\circ} \mathrm{C}(52 \%)$ in the Lausanne case. These values are somewhat larger than those derived when no mechanical loading was present (i.e. $192 \mathrm{kPa} /{ }^{\circ} \mathrm{C}(56 \%)$, and $104 \mathrm{kPa} /{ }^{\circ} \mathrm{C}$ (36\%) for each case respectively; see Fig. 7).

In the London main test pile, during the first cooling stage, the maximum stress (at $15 \mathrm{~m}$ depth) in the pile equates to an additional axial stress of about $177 \mathrm{kPa} /{ }^{\circ} \mathrm{C}$, which is comparable (within 10\%) to the value of $192 \mathrm{kPa} /{ }^{\circ} \mathrm{C}$ obtained on first heating loading of the heat sink pile. In the main test pile, the subsequent heating invoked a larger thermal stress response than in the primary cooling. The maximum stress

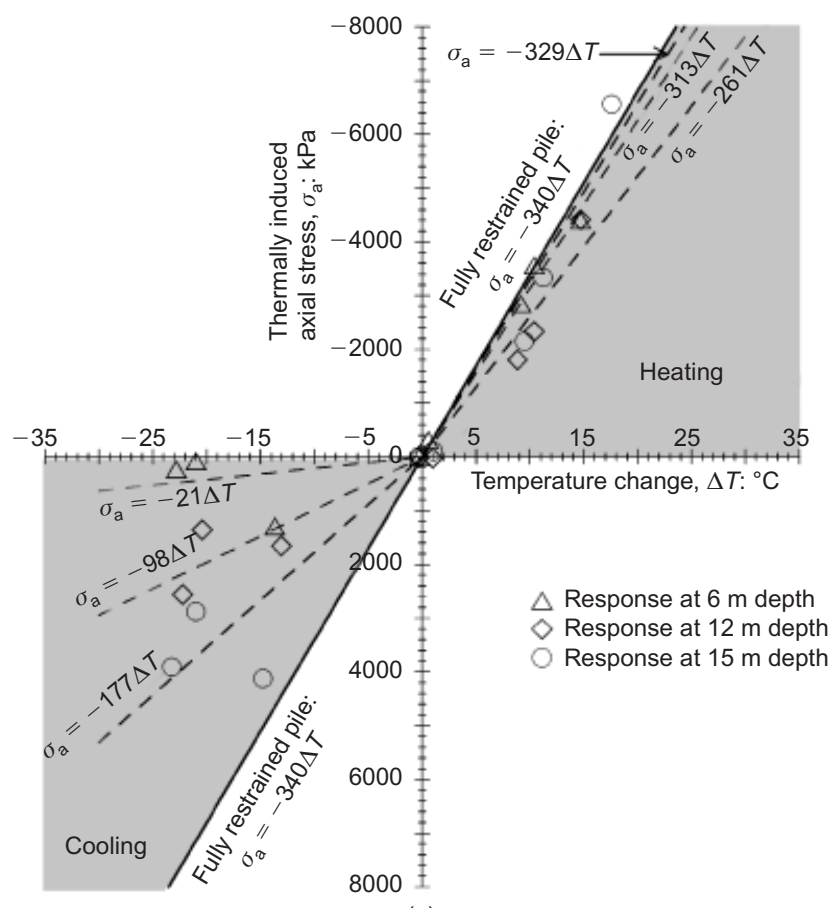

(a)

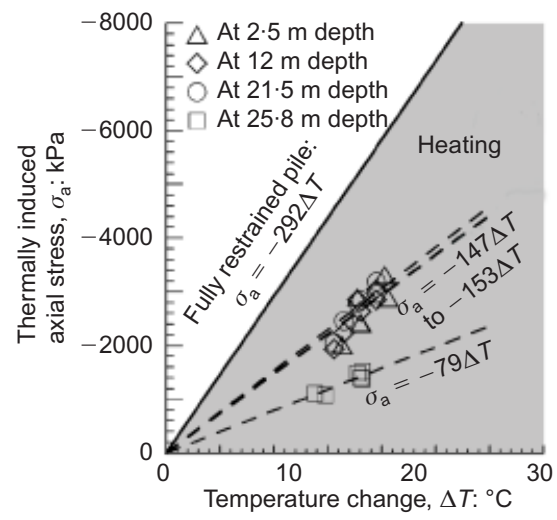

(b)

Fig. 16. Variation of pile axial stress in response to temperature change in: (a) London main test pile; (b) Lausanne tests T-2 to T-7 response was close to the condition for a fully restrained pile (Fig. 16(a)). There could be an impact of the earlier thermal phase in the latter, that is, residual thermal stresses and/or changes in the available shaft resistance resulting from thermally induced changes in the diameter of the pile (Ouyang et al., 2011). Further investigation of these possible effects is needed. However, the result does suggest that consideration of the thermal stresses associated with perfect restraint of the shaft would provide a suitable upper bound for design.

The larger values obtained in the London test than in the Lausanne case are thought to be due to stronger pile-soil interaction; the soil (stiff clay) in the London case is considered to be significantly stiffer than the soil (mostly soft clay) in the Lausanne case. Despite the pile having been heated and cooled several times, the thermal response of the Lausanne test pile remains well below that of a perfectly restrained pile.

In the test sequence from $\mathrm{T}-1$ to $\mathrm{T}-7$, an increase in the average thermal response from about $-50 \mathrm{kPa} /{ }^{\circ} \mathrm{C}(17 \%$ of fully restrained value) to about $-150 \mathrm{kPa} /{ }^{\circ} \mathrm{C}(51 \%)$ is seen at the pile head, and this may be due to the increasing level of restraint developing as the building was constructed. In support of this, between test $\mathrm{T}-1$ and test $\mathrm{T}-2$ when the building was at first floor level, the thermal response at the pile head increased from about $-50 \mathrm{kPa} /{ }^{\circ} \mathrm{C}$ to $-120 \mathrm{kPa} /{ }^{\circ} \mathrm{C}$, and in subsequent stages (T-2 to T-7) increased by another third.

Thermally induced stress at the head in the Bad Schallerbach case was about $-192 \mathrm{kPa}$ by $7^{\circ} \mathrm{C}$ heating (or $-27 \mathrm{kPa} /{ }^{\circ} \mathrm{C}$ ), which is significantly smaller than the Lausanne case $\left(-150 \mathrm{kPa} /{ }^{\circ} \mathrm{C}\right)$. The greater thermal stress response developed in the Lausanne case is possibly due to the fact that only one pile within the entire foundation system was heated, and thus the energy pile was expanding into the entire mass of the overlying structure. Most of the piles at Bad Schallerbach were used as energy piles, and hence the whole pile group would have responded to thermal loading by expanding and contracting in unison, with less end restraint perhaps a consequence. In the London case, the pile head was allowed to move freely as it was a load-controlled test: hence there was very little thermally induced stress at the pile head.

Where present, end restraint at the toe also appears to have created a thermal load response. In the Lausanne case, the thermally induced stress per unit temperature increase was about $-79 \mathrm{kPa} /{ }^{\circ} \mathrm{C}$, as shown in Fig. $16(\mathrm{~b})$, and showed very little variation from test to test.

\section{Thermally mobilised shaft resistance changes}

It is important to confirm that the total mobilised shaft resistance developed during thermo-mechanical loading is within the permissible range of ultimate shaft resistance, with some margin of safety. In the London case (Fig. $17(\mathrm{a}-\mathrm{i})$ ), it is observed that in the first cooling phase axial contraction developed additional shaft resistance over the upper section and 'negative' shaft resistance over the lower sections. The shaft resistance profile is similar to the conceptual one presented in Fig. 10(c). The shaft resistance mobilised between $5 \mathrm{~m}$ and $12 \mathrm{~m}$ depth (upper section) after cooling was about $80 \mathrm{kPa}$, about two-thirds of the estimated average ultimate shaft resistance of $120 \mathrm{kPa}$, which was estimated from a load test completed at the end of the testing programme. This is an increase of $40 \mathrm{kPa}$ in mobilised shaft resistance from the value of $40 \mathrm{kPa}$ due to mechanical loading only. In this primary cooling phase, the change in shaft resistance due to a unit degree change in temperature is approximately $2 \cdot 1 \mathrm{kPa} /{ }^{\circ} \mathrm{C}$, a value comparable 


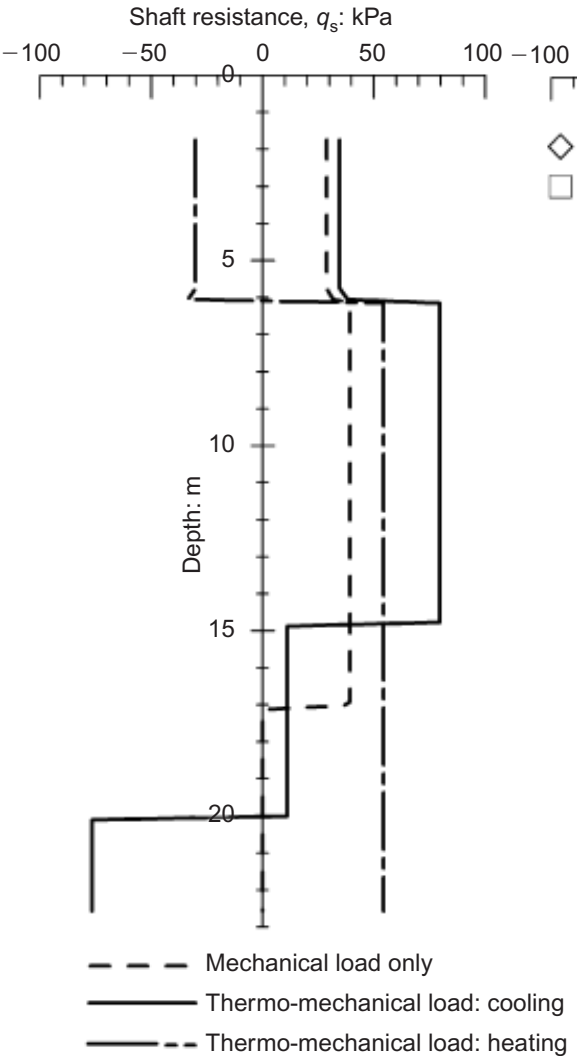

(a)
Shaft resistance, $q_{\mathrm{s}}: \mathrm{KPa}$

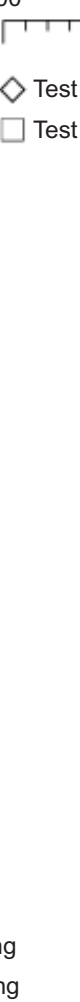

(1)

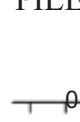

Shaft resistance, $q_{\mathrm{s}}: \mathrm{kPa}$

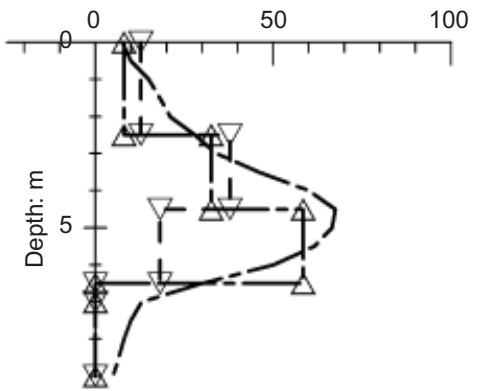

$\nabla-\nabla$ Mechanical load only

$\triangle-\triangle$ Thermo-mechanical load from Brandl (1998) strain profile

Thermo-mechanical loading direct from Brandl (1998)

(c)

Fig. 17. Pile shaft friction mobilised in response to temperature change in: (a) London main test pile; (b) Lausanne tests T-6 and T-7; (c) Bad Schallerbach

to the $2 \cdot 1-2 \cdot 5 \mathrm{kPa} /{ }^{\circ} \mathrm{C}$ obtained from the heat sink pile during its primary (heating) thermal loading (see Fig. 9). Over the lower section $(20-22.5 \mathrm{~m})$, a negative shaft friction of approximately $-76 \mathrm{kPa}$ develops. Hence the change in shaft resistance due to a unit degree change in temperature is approximately $-4.0 \mathrm{kPa} /{ }^{\circ} \mathrm{C}$, which is larger than the values obtained from the heat sink pile.

In the subsequent heating phase (Fig. 17(a)), 'negative' shaft resistance of about $-30 \mathrm{kPa}$ is mobilised over the top section (to $6 \mathrm{~m}$ depth) as the pile expands upwards. There is positive shaft resistance of about $55 \mathrm{kPa}$ below (depth from $6 \mathrm{~m}$ to $23 \mathrm{~m}$ ) as the pile expands downwards. The shaft resistance profile is similar to the conceptual one presented in Fig. 10(e). From the mechanical loading only state, the change in shaft resistance due to a unit degree change in temperature is approximately $-5.9 \mathrm{kPa} /{ }^{\circ} \mathrm{C}$ at the top section (0-6 m depth), $1.5 \mathrm{kPa} /{ }^{\circ} \mathrm{C}$ at the middle section $(6-15 \mathrm{~m}$ depth) and $5.4 \mathrm{kPa} /{ }^{\circ} \mathrm{C}$ at the bottom section (below $7 \mathrm{~m}$ depth). In general, a greater increase in shaft resistance is observed when the pile is loaded and heated. The radial expansion of the pile is noted during heating (Amis et al., 2008), and this may have contributed to the observed increase in shaft resistance.

The heating phase in the Lausanne case (Fig. 17(b)) shows broadly the same trend as the London test: the upper section exhibited additional 'negative' shaft resistance, whereas the lower section exhibited additional positive shaft resistance. However, the shaft resistance profiles derived are complicated, owing to the layered soil condition and changes in diameter, and the values quoted are rather approximate, as they are computed from few strain data, as shown in Fig. 14(b). From the mechanical loading only state, an increase in temperature of about $18^{\circ} \mathrm{C}$ mobilised additional shaft resistance of about $-45 \mathrm{kPa}\left(-2.5 \mathrm{kPa} /{ }^{\circ} \mathrm{C}\right)$ in the soft alluvial clay $\left(5-12 \mathrm{~m}\right.$ depth) and $90 \mathrm{kPa}\left(5 \mathrm{kPa} /{ }^{\circ} \mathrm{C}\right)$ in the stiff till (22-25 $\mathrm{m}$ depth). The change in shaft resistance in the soft alluvial clay is about the same as that in T-1 (about $-2.5 \mathrm{kPa} /{ }^{\circ} \mathrm{C}$ ), whereas the change in the stiff till is much greater than that in $\mathrm{T}-1$ (about $0.9 \mathrm{kPa} /{ }^{\circ} \mathrm{C}$ ). In contrast, the middle section, which is in soft sandy gravelly till, exhibited less change in shaft resistance in these cases $\left(0.5 \mathrm{kPa} /{ }^{\circ} \mathrm{C}\right)$ as well as in T-1 when there was no building load (see Fig. 8). In the top $5 \mathrm{~m}$ section, an increase in the shaft resistance was deduced rather than the expected decrease, which requires further investigation. However, the results highlight the variation of thermo-mechanical response in different soil types.

The shaft resistance profile obtained at the Bad Schallerbach case is shown in Fig. 17(c). The top section was warmed, and a decrease in shaft resistance is evident between 0 and $2.5 \mathrm{~m}$ depth, a result of the pile expanding upwards. The cooled mid-section from $4.5 \mathrm{~m}$ to $6.5 \mathrm{~m}$ depth shows an increase in shaft resistance, indicating that the pile was moving downwards relative to the surrounding soil. Based on the limited data, the mobilised shaft resistance was found to change by about $40 \mathrm{kPa}$ (or $2.7 \mathrm{kPa} /{ }^{\circ} \mathrm{C}$ ) over the mid-section (4.5-6.5 m depth). Here it also appears that shaft resistance at the section above (2.5-4.5 $\mathrm{m}$ depth) may have already been close to its limiting value, and so any additional restraint had to be mobilised in the section below where resistance was presumably only partially mobilised; the $4.5 \mathrm{~m}$ level equates to the indicated depth of the interface between the colluvium and in situ Tertiary sediments (Brandl, 1998). 


\section{CONCLUSIONS}

During heating and cooling cycles, energy piles expand and contract, and this changes the pile-soil interaction. In some cases this may result in unwanted consequences, such as additional building settlement, tensile axial stresses, large compressive axial stresses or mobilisation of limiting resistance on the pile shaft. This paper has examined the magnitude of some of these interactions, evident from three field cases. Simplified descriptive load transfer mechanisms for a pile subjected to thermal loading only (i.e. without mechanical load) and thermo-mechanical loading are further developed and validated against the responses measured in the field cases.

The induced effects measured by the three field trials for thermal load or thermo-mechanical load are summarised in Table 2. The difference in the magnitude is attributed mainly to ground conditions, end restraint and thermal load.

These field data have provided good insights into the behaviour of energy foundation systems, but all have their shortcomings and limitations. The London case was undertaken within a limited time frame on an active construction site, and used extreme temperature cycles. The Lausanne case involved heating pulses only, and the energy test pile sat in among a foundation system that was otherwise not used in a GSHP system. Although the Bad Schallerbach case was conducted for more than a year as part of an operational GSHP, only very limited data have been published for it.

When a pile was heated or cooled, the thermally induced axial stress inside the pile was between about $50 \%$ and $100 \%$ of the theoretical fully restrained values. The latter provides a safe upper bound for estimates of stress change in design. However, the mechanisms by which this effect is mitigated in (for example) the Lausanne test need to be understood in order to develop more refined design guidance, and to avoid excessive conservatism.

End restraint is also important. Imposed mechanical load or the rigidity of the superstructure may generate some degree of restraint at the pile head, and similarly the pile toe may be restrained when stiff ground or rock is present. The large thermal stress developed at the pile head in the Lausanne case may be unrepresentative of situations where many piles are heated or cooled at the same time. At Bad Schallerbach, where this was the case, the axial thermal stress at the pile head was significantly lower.

The mobilised shaft resistance profile for a mechanically loaded pile may undergo significant changes during thermal loading. Patterns of behaviour are broadly consistent with the simple schematic descriptions proposed. As might be expected, stiff silty/clayey soils (London Clay, lower part of Lausanne pile: $2 \cdot 1 \mathrm{kPa} /{ }^{\circ} \mathrm{C}$ to $5.9 \mathrm{kPa} /{ }^{\circ} \mathrm{C}$ ) appear to exhibit larger unit mobilisation of shaft resistance per unit change in temperature than soft clayey soil (upper part of Lausanne pile: $1.5 \mathrm{kPa} /{ }^{\circ} \mathrm{C}$ to $2.5 \mathrm{kPa} /{ }^{\circ} \mathrm{C}$ ). However, simple and reliable quantitative estimation of these effects is some way off, particularly in layered soil conditions, and methods for predicting these effects need to be developed.

This study focused on the change in axial stress and mobilised shaft resistance of energy piles in response to heating and cooling, which is a step towards more refined design of energy piles. By ensuring that design concrete stresses are not exceeded, conventional factors of safety for skin friction and end bearing are maintained, and foundation settlements are limited, the heating and cooling of energy piles are unlikely to have any detrimental effect on buildings. Possible impacts of pile group layout and operation of energy piles on pile settlement response are also an important aspect to consider in design, and are part of ongoing investigations (e.g. Ouyang et al., 2011).

\section{ACKNOWLEDGEMENTS}

The authors would like to express their gratitude to Cementation Skanska Limited and Geothermal International Limited for their support in this and ongoing projects, and also to the colleagues without whose assistance the tests at Lambeth College and EPFL would not have been as successful as it has been. 'Energy Piles' is a registered trademark of Cementation Skanska Limited and has been used with its permission.

Table 2. Summary of pile response to thermo-mechanical loading

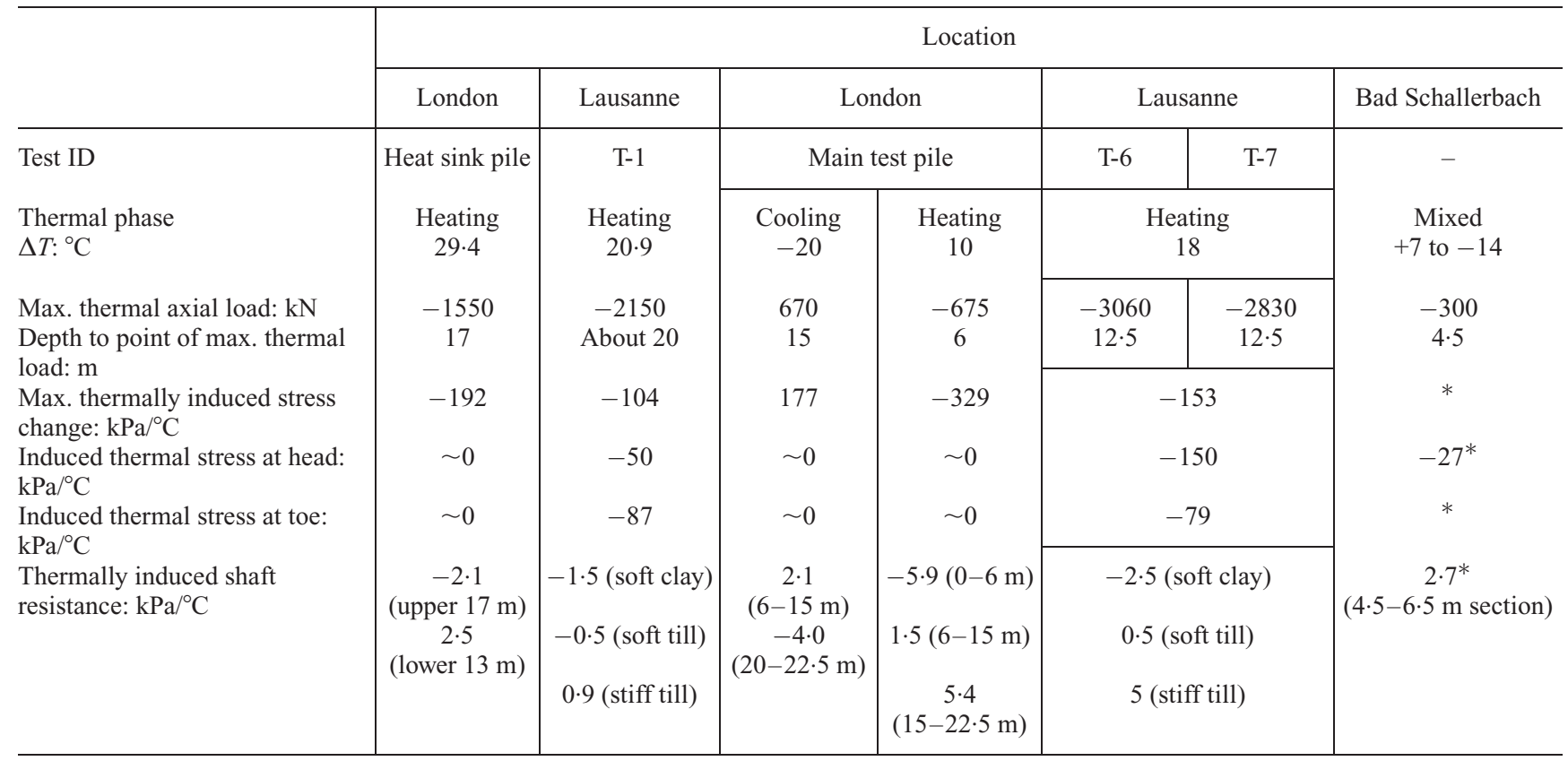

Note: Compression negative; bgl = below ground level

* Indicative, or not possible to assess owing to non-uniform temperature profile 


\section{REFERENCES}

Amis, A., Bourne-Webb, P., Amatya, B., Soga, K. \& Davidson, C. (2008). The effects of heating and cooling energy piles under working load at Lambeth College. Proc. 33rd Ann. and 11th Int. DFI Conf., New York, article no. 1620.

Bourne-Webb, P., Amatya, B. L., Soga, K., Amis, T., Davidson, C. \& Payne, P. (2009). Energy pile test at Lambeth College, London: geotechnical and thermodynamic aspects of pile response to heat cycles. Géotechnique 59, No. 3, 237-248, http:// dx.doi.org/10.1680/geot.2009.59.3.237.

Bourne-Webb, P. J., Amatya, B. L. \& Soga, K. (2012). A framework for understanding energy pile behaviour. Proc. Instn Civ. Engrs Geotech. Engng, http://dx.doi.org/10.1680/geng.10.00098.

Brandl, H. (1998). Energy piles and diaphragm walls for heat transfer from and into the ground. Proc. 3rd Int. Symp. on Deep Foundations on Bored and Auger Piles, BAP III, Ghent, 37-60.

Brandl, H. (2006). Energy foundations and other thermo-active ground structures. Géotechnique 56, No. 2, 81-122, http:/ dx.doi.org/10.1680/geot.2006.56.2.81.

Ennigkeit, A. \& Katzenbach, R. (2001). The double use of piles as foundation and heat exchanging elements. Proc. 15th Int. Conf. Soil Mech. Geotech. Engng, Istanbul, 893-896.

Laloui, L., Moreni, M. \& Vulliet, L. (2003). Comportement d'un pieu bi-fonction, fondation et échangeur de chaleur. Can. Geotech. J., 40, No. 2, 388-402.

Laloui, L., Nuth, M. \& Vulliet, L. (2006). Experimental and numerical investigations of the behaviour of a heat exchanger pile. Int. J. Numer. Anal. Methods Geomech. 30, No. 8, 763781.

Ouyang, Y., Soga, K. \& Leung, Y. F. (2011). Numerical back analysis of energy pile test at Lambeth College, London. Proc. ASCE GeoFrontiers 2011 Conf., Dallas, TX, Han, J. and Alzamora, D. E., eds, pp. 440-449, http://dx.doi.org/10.1061/ 41165(397)46. 